\title{
Psammophilous halacarids (Halacaridae, Acari) from Dampier, Western Australia. Description of species and faunal comparison of the mesopsammal halacarid fauna of western and eastern Australia
}

\author{
Ilse Bartsch \\ Forschungsinstitut Senckenberg, c/o DESY, Notkestr. 31, 22607 Hamburg, Germany \\ e-mail bartsch@meeresforschung.de
}

\begin{abstract}
Twelve species of halacarid mites were extracted from tidal and subtidal sandy deposits and coral fragments in the tropical Dampier area, Western Australia. The genera and number of species (in parentheses) are: Actacarus (2), Anomalohalacarus (1), Arhodeoporus (1), Copidognathus (1), Scapthognathides (2), Scapthognathus (1), and Simognathus (4). All species are diagnosed and four species, new to science, are described, viz. Actacarus festivus sp. nov., Anomalohalacarus dampierensis sp. nov., Simognathus salebrosus sp. nov., and Simognathus tener sp. nov. Seven of the twelve species are known from the Indo-Pacific region, from warm-temperate Western Australia, tropical eastern coast of Australia, Hawaiian Islands, and/or off Chile.
\end{abstract}

Key words: Australia, marine mites, psammobionts, new species, faunal comparison

\section{INTRODUCTION}

Sandy deposits with medium and coarse grain fractions provide a system with a large surface, different-sized void volumes and regular interstitial water replenishment but shelter from extreme amplitudes of environmental parameters. These deposits contain a specialized fauna, the interstitial fauna or mesopsammon, terms introduced by Nicholls (1935) and Remane (1940).

The first records of mesopsammic halacarid species from Australia were from Rottnest Island, Western Australia, an island with a variety of sandy deposits. About 30 psammophilous halacarid mites from intertidal and subtidal sandy deposits have been described (Bartsch 1993). Otto (1999a, b, 2000a-e, g, 2001a-c), Otto and Bartsch (1999) and (Bartsch 2000) added more than 50 new records to the list of Australian species extracted from sandy deposits on the northeastern coast of Australia, many of them being psammophilous. Examination of both tidal and subtidal sediments collected near Dampier, tropical Western Australia, resulted in both new records and new halacarid species.

\section{STUDY AREA, MATERIAL AND METHODS}

Dampier, on the Burrup Peninsula, lies in the tropical north of Western Australia, at about $20^{\circ} \mathrm{S}$, $117^{\circ} \mathrm{E}$. The shoreline is characterized by rocky platforms, rocks and mangroves. Areas with sandy deposits with medium and coarse sand are rare. Subtidal deposits immediately off Dampier are rich in organic material and typical arenicolous halacarids are generally lacking, but around the outer islands of the Dampier Archipelago there are coarse sediments with a psammophilous meiofauna

The mites were extracted from the sand by frequently stirring with water and decanting through a sieve with $100 \mu \mathrm{m}$ mesh diameter. The mites were cleared in lactic acid and mounted in glycerin jelly. Type and voucher specimens are deposited in the Western Australian Museum, Perth (WAM).

Abbreviations used in the descriptions: $A D=$ anterior dorsal plate; $\mathrm{AE}=$ anterior epimeral plate; ds- 1 to ds- $6=$ first to sixth dorsal idiosomatic seta $(\mathrm{e}) ; \mathrm{GA}=$ genitoanal plate; $\mathrm{GO}=$ genital opening; $\mathrm{OC}=$ ocular plate(s) $\mathrm{P}=$ palp, $\mathrm{P}-1$ to $\mathrm{P}-4=$ first to fourth palpal segment; pas = parambulacral seta(e); $\mathrm{PD}=$ posterior dorsal plate; $\mathrm{PE}=$ posterior epimeral plate(s); pgs = perigenital setae; $\mathrm{sgs}=$ subgenital setae. The legs are numbered I to IV, leg segments 1 to 6 are trochanter, basifemur, telofemur, genu, tibia, and tarsus.

Except one species recently described and figured on the base of specimens from Dampier (Bartsch 2003b), the species are diagnosed and illustrated, in general relying on individuals from the Dampier area. In the bibliography of a given species only the most relevant descriptive papers are cited. 


\section{SYSTEMATICS}

Subfamily Actacarinae Viets, 1939

Genus Actacarus Schulz, 1937

Actacarus festivus sp. nov.

Figure $1 \mathrm{~A}-\mathrm{H}$

\section{Material Examined}

\section{Holotype}

Female, sponge garden, West of Rocky Head, $20^{\circ} 32.1^{\prime} \mathrm{S}, 116^{\circ} 26.7^{\prime} \mathrm{E}$, Enderby Island, Dampier Archipelago, Western Australia, Australia; 2-13 m, unsorted sandy deposits, 3 August 2000, coll. C. Bryce (WAM T52095).

\section{Etymology}

Specific name from festivus, Latin, nice, festive.

\section{Diagnosis}

Idiosomal length $205 \mu \mathrm{m}$. Dorsal and ventral plates uniformly porose. Opposing margins of $A D$ and $P D$ and $A E$ and GA truncate. Length of PD less than twice that of AD. Setae ds-2 within striated Integument. PE with three setae; one pair of setae within striated integument. Anterolateral margins of GA converging. Ovipositor extending beyond GA. Gnathosoma 0.28 of length of idiosoma. Rostrum extending slightly beyond middle of P-2. Tectum arched. Tibia I with three slender ventral setae, tibiae II to IV each with one faintly bipectinate seta. Claws on tarsi II to IV with long, coarse tines.

\section{Description}

\section{Female}

Idiosoma. Length $205 \mu \mathrm{m}$, width $115 \mu \mathrm{m}$. Dorsal plates uniformly and minutely porose; with few striae of membraneous integument between opposing margins of $\mathrm{AD}$ and $\mathrm{PD} . \mathrm{AD}$ wider than long (Figure 1A), length $67 \mu \mathrm{m}$, width $88 \mu \mathrm{m}$; anterior margin arched, posterior margin almost truncate. Gland pores in lateral margin. $O C$ triangular, length $15 \mu \mathrm{m}$, width $7 \mu \mathrm{m}$; with gland pore and pore canaliculus. Length of PD $127 \mu \mathrm{m}$, width $90 \mu \mathrm{m}$; its length 1.9 times that of $A D$. PD with two pairs of gland pores, anterior pair somewhat posterior to level with insertion of leg IV. Dorsal setae small, pair of ds-1 slightly posterior to the level of gland pores. Pair of ds- 2 in striated integument; ds- 3 to ds- 5 on PD, arranged as illustrated. Pair of ds-5 level with gland pores. Pair of ds- 6 on anal plate.

Length of $\mathrm{AE} 91 \mu \mathrm{m}$, width $103 \mu \mathrm{m}$; with three pairs of setae; posterior margin of $\mathrm{AE}$ truncate (Figure 1B). PE extending beyond insertion of leg IV. One pair of setae within striated integument between PE. Length of GA $87 \mu \mathrm{m}$, width $72 \mu \mathrm{m}$; anterior margin truncate, lateral margin diverging from anterior margin to level with posterior edge of PE. GA with three pairs of pgs. Ovipositor long, extending beyond anterior margin of GA and posterior margin of $\mathrm{AE}$.

Gnathosoma. Length $59 \mu \mathrm{m}$, width $46 \mu \mathrm{m}, 1.2$ times longer than wide. Gnathosoma 0.28 of length of idiosoma. Tectum broadly arched (Figure 1D). Rostrum short, far from reaching end of P-2. P-2 with a dorsal seta. P-3 with spiniform medial process. P-4 with three setae in basal whorl, one spur, one ventral and lateral seta, and a spur-like tip (Figure 1C).

Legs. Leg IV longer than leg I. Lateral flanks of legs I and II delicately punctate. Tibia I with slender base, then widened; its length surpassing that of telofemur I. Tibiae and relevant telofemora of following legs similar in length. Telofemur I 1.8 times longer than high. Leg chaetotaxy (solenidia included, pas excluded): leg I, 0, 2, 3, 5, 7, 7 (Figure 1E); leg II, 0, 2, 3, 4, 5, 4 (Figure 1F); legs III and IV, 1, 2, 2, 3, 5, 3 (Figures $1 \mathrm{G}$ and H). Genu II with dorsal alveolus but no seta seen. Tibia I with three slender ventral setae, a ventrolateral seta and three dorsal setae. On tibia II ventromedial seta slightly wider than ventral seta. Ventromedial seta on tibia III long and wide, apical seta of tibia III only slightly widened. Ventromedial seta of tibia IV delicately widened, apical seta slender. Tarsi I to IV each with pair of pas.

Length of claws increasing from tarsus I to III. Claws on tarsus I with accessory process but no pecten. Pectines of claws II to IV with very coarse tines. Central sclerite with small bidentate process.

\section{Remarks}

Actacarus festivus has a short PD relative to the length of the $A D$, there is one pair of setae within the membraneous ventral integument, and the margins of the female GA are convergent instead of almost parallel-sided. The characters are shared with A. giganteus Krantz, 1971, a species recorded from the Caribbean (Krantz, 1971). The Caribbean species is somewhat larger, its idiosoma and the dorsal and ventral plates are more slender than in $A$. festivus, the dorsal plates are coarsely punctate in $A$. giganteus but minutely porose in $A$. festivus.

The arrangement of the dorsal plates resembles that of $A$. latus Newell, 1984 . Beside the number of setae on the $\mathrm{AE}$ (three in A. festivus, four in A. latus) there are differences in the size (length of female $205 \mu \mathrm{m}$ in A. festivus, 334-355 in A. latus), the ornamentation of the dorsal plates (minutely and uniformly porose in A. festivus, pitted in A. latus), shape of the female GA and the arrangement of the pgs. Actacarus latus is recorded from the Eastern Pacific, from off the coast of Chile (Newell, 1984).

The shape of the female GA of A. australis Bartsch, 

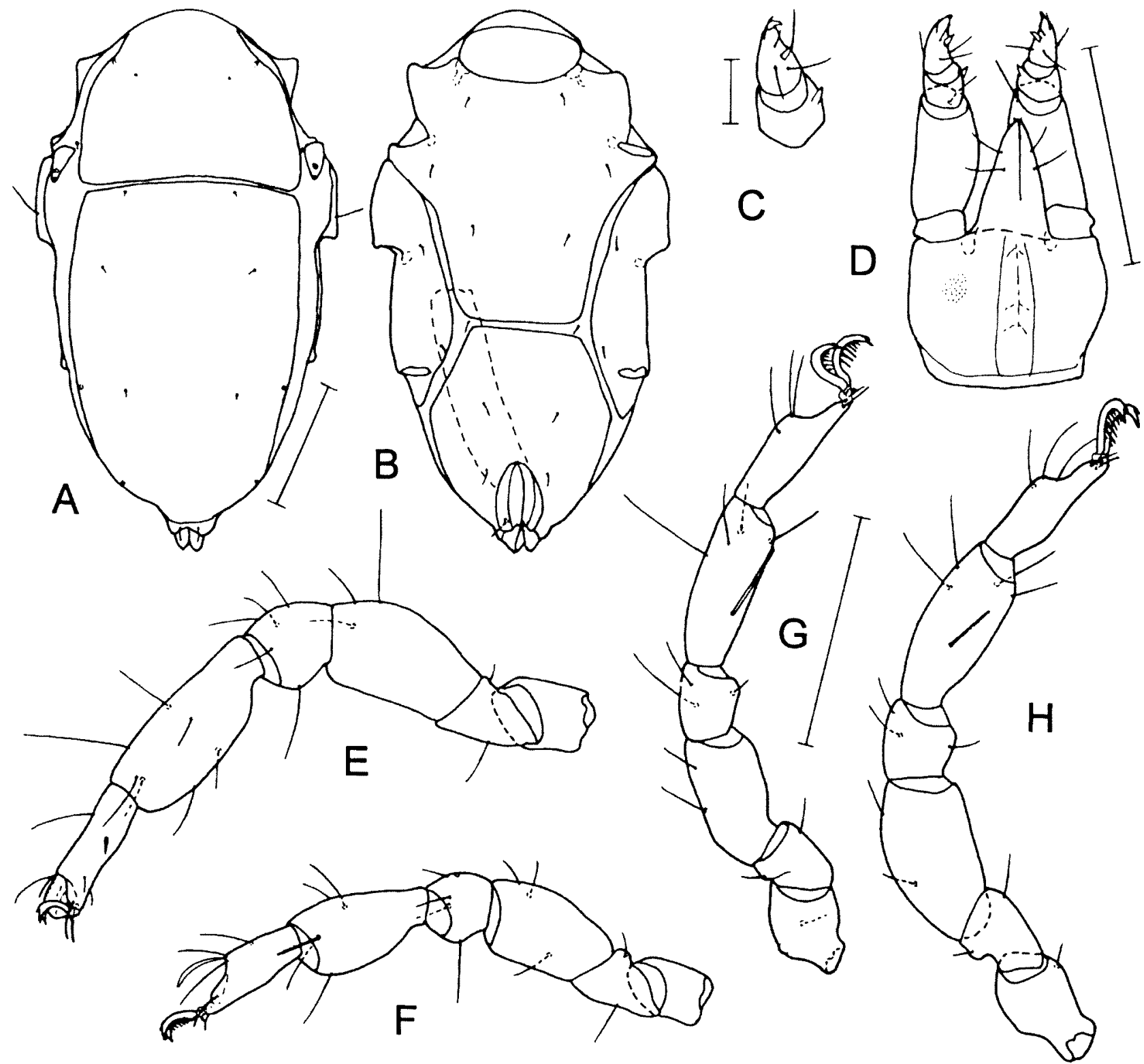

Figure 1 A-H. Actacarus festivus sp. nov., female. A, Idiosoma, dorsal; B, idiosoma, ventral; C, P-3 and P-4, ventral; D, gnathosoma, ventral; E, leg I, medial; F, leg II, medial; G, leg III, medial; H, leg IV, medial. Scale = 50 $\mu \mathrm{m}$ $(\mathrm{A}, \mathrm{B}, \mathrm{D}-\mathrm{H})$; scale $=10 \mu \mathrm{m}(\mathrm{C})$.

1993 is similar to that of $A$. festivus. In contrast to $A$. festivus the $\mathrm{PE}$ of $A$. australis bears three ventral setae and the ovipositor is much shorter.

\section{Distribution}

Indian Ocean, Western Australia, Dampier. From shallow water deposits.

\section{Actacarus pacificus Bartsch, 1979}

Figure 2A-D

Actacarus pacificus Bartsch, 1979: 231-234, figures 1-

14; Bartsch, 1993: 75, 76, figure 1; Abé, 1997: 33 34 , figure $2 \mathrm{~A}-\mathrm{C}$.

Actacarus orthotectus Newell, 1984: 245-247, figures 705-707.
Actacarus marindicus Otto, 2000c: 116-119, figures $3 a-e, 4 a-e$ (new synonymy).

\section{Material Examined}

Australia: Western Australia: 1 female, Dampier, $20^{\circ} 39^{\prime} \mathrm{S}, 116^{\circ} 42^{\prime} \mathrm{E}$, sandy beach, coarse, unsorted sand in middle part of tidal slope, $0-3 \mathrm{~cm}$ sediment depth, 3 August 2000, coll. I. Bartsch (WAM T52096)

\section{Diagnosis}

Idiosomal length $263 \mu \mathrm{m}$. Dorsal and ventral plates with delicate punctation. Opposing margins of $\mathrm{AD}$ and $\mathrm{PD}$ and $\mathrm{AE}$ and $\mathrm{GA}$ truncate (Figure 2A). PD more than twice the length of AD. OC with triangular anterior portion extending beyond gland pore. Pair of ds- 2 within membraneous integument. 

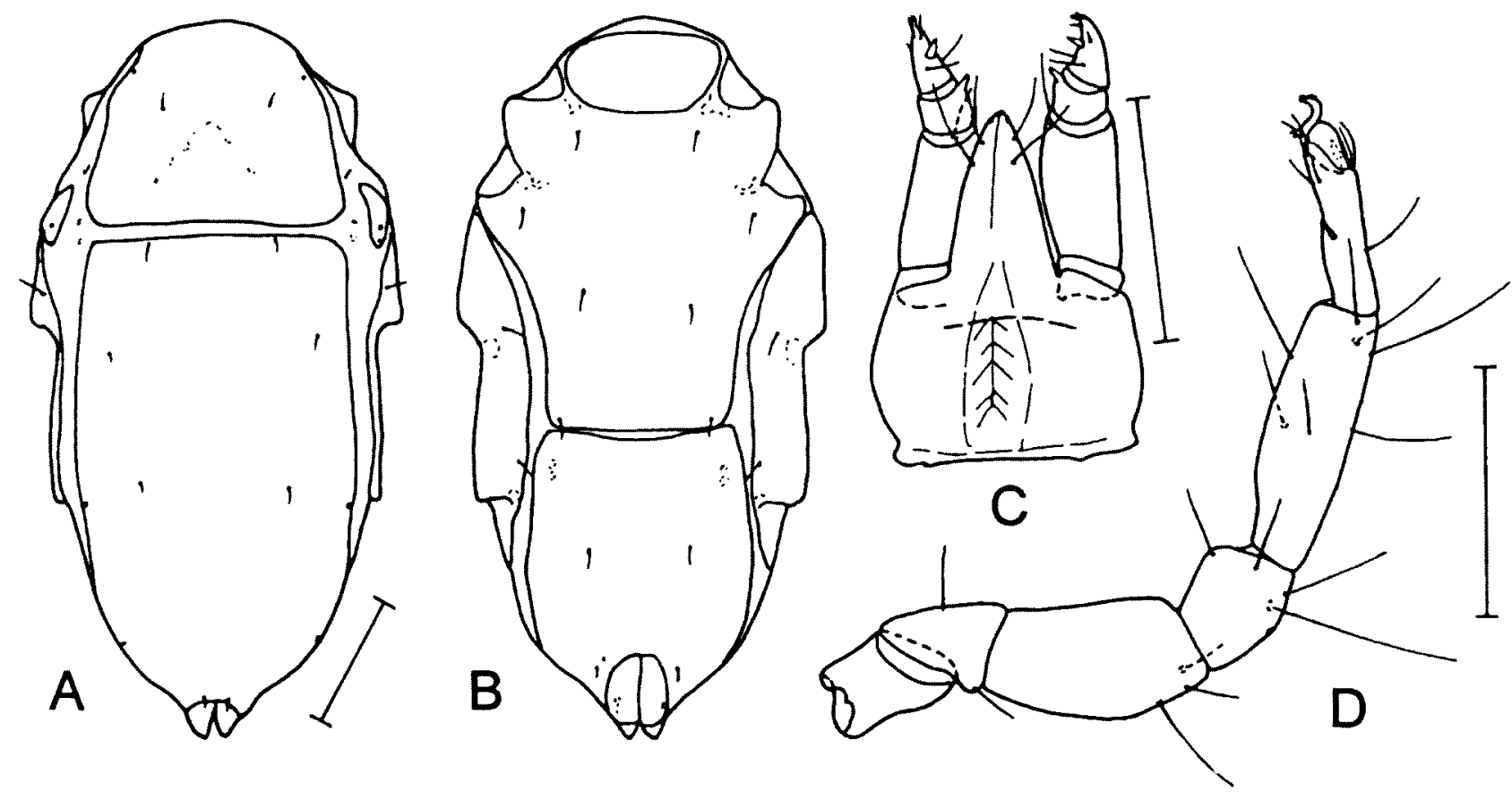

Figure 2 A-D. Actacarus pacificus Bartsch, 1979, female. A, Idiosoma, dorsal; B, idiosoma, ventral; C, gnathosoma, ventral; $D$, leg I, medial. Scale $=50 \mu \mathrm{m}$.

AE with four pairs of setae. PE with one dorsal and two ventral setae (Figure 2B). Ovipositor in rest extending beyond anterior margin of GA. Gnathosoma 0.27 of idiosomal length. Rostrum about as long as gnathosomal base. Tectum very slightly arched. Rostrum extending almost to end of P-2 (Figure 2C). Both pairs of maxillary setae in distal half of rostrum. Legs less than 0.7 of idiosomal length. Genua shorter than telofemora and tibiae. Leg chaetotaxy: leg I, 0, 2, 3, 5?, 7, 7; leg II, $0,2,3,4,5$, 4; legs III and IV , 1, 2, 2, 3, 5, 3. Tibia I with three slender ventral setae (Figure 2D); tibiae II to IV with two ventral setae, on tibia III these setae faintly bipectinate. Paired claws on tarsus I with accessory process but no pecten, claws II to IV with few large tines.

\section{Remarks}

According to Bartsch (1993) and Abé (1997), Actacarus pacificus is found widely spread in the Indo-Pacific region. In contrast, Otto (2000c) expected specimens from Rottnest Island, Western Australia, collected and identified by Bartsch (1993), not to be identical with $A$. pacificus. Otto described the Australian specimens under the name of Actacarus marindicus Otto, 2000. The differences between the individuals from the Hawaiian Islands and Australia were said to be (1) a coarser punctation of the PD in the Hawaiian material and (2) presence of a single bipectinate seta on tibia III of the type specimens, instead of two such setae as present in the Australian individuals. In respect to the first mentioned character, the differences stated by Otto $(2000 \mathrm{c}$ ) cannot be confirmed by the present author. The dorsal plates of the holo- and paratype female and male of $A$. pacificus are delicately punctate, as the ventral plates are. Unfortunately, Otto (2000c) did not mention if the illustration (Otto, 2000c: figure 8b) was prepared on the base of the holo- or a paratype, a female or male. In the illustration the position of the setae assumedly representing the ds-4 is unusual (and not corresponding to the situation in either the holotype or the paratypes), and the ds-3 are not illustrated. The second character used by Otto (2000c) to distinguish between $A$. pacificus and $A$. marindicus was the shape of a seta on tibia III. The basal one of the two ventral setae on tibia III is longer than the distal one and delicately bipectinate. The distal seta has fuzzy margins and such a tip (Otto, 2000c: 118) due to a very subtle bipectination. These fuzzy margins are not recognizable when viewing the edge of that seta. Presence or absence of fuzzy margins is inadequate for discriminating between species as their perceptibility is influenced by the preservation, storing, clearing and mounting medium.

Bartsch (1993: 76) mentioned the shape of the basal seta on tibia I as a possible diagnostic character to distinguish between the Hawaiian and Western Australian specimens. A re-examination of the holo- and paratypes showed that the relevant seta is somewhat more stout than the other ventral setae but not distinctly pectinate.

Otto (2000c) also discussed the state of $A$. orthotectus Newell, 1984. That species was described from the Juan Fernandez Islands, Chile (Newell, 1984). Bartsch (1993) and Abé (1997) believed it to 
be synonymous with $A$. pacificus. Otto (2000c) reestablished the Chilean species ( $A$. orthotectus) because of its slender $\mathrm{P}-2$ and presented an illustration of the palps of both a Chilean and Western Australian specimen (Otto, 2000c: figure $3 \mathrm{e}$ and $f)$. The palps are said to show a lateral aspect. In general, the P-2 of Actacarus species are slightly flattened but narrow in dorsal aspect. It is likely that one of the illustrations (Otto, 2000c: figure 3f) represents a dorsolateral aspect of the palps, a notion corroborated by the insertion of the dorsal seta in that figure. In lateral aspect the shape of the palps may be the same in specimens from both the southeastern and northern Pacific.

Nonetheless, several cryptic species may exist in the Indo-Pacific region, each restricted to a smallscale geographical area, and the specimens from Rottnest Island (A. marindicus) may prove to be distinct. The presently described morphological characters allow no separation between individuals from the Hawaiian Islands and Western Australia.

The Actacarus species recorded from Australia are A. australis, A. chelonis Otto, 2000, A. cornutus Otto, 2000, A. nanus Otto, 2000, A. pacificus, A. spinosus Otto, 2000, and the above described $A$. festivus. The $\mathrm{AE}$ of each of $A$. pacificus, A. nanus and A. spinosus bears four pairs of setae, the PE two ventral setae. A. spinosus, the smallest species, has an idiosomal length of $186-194 \mu \mathrm{m}$, its P-4 has a conspicuously bent seta (instead of a spur), on tibia I is one of the ventral setae coarsely bipectinate, one faintly pectinate, tibiae III and IV both bear one long bipectinate and one very short and slender ventral seta. Actacarus nanus has an idiosomal length of 198-212 $\mu \mathrm{m}$, the ds-2 are close to the level of the posterior margin of the $\mathrm{AD}$ and the $\mathrm{OC}$ are rather short, the female GA is short, the distance from the anterior margin of the GO to the GA almost equals half the length of the $\mathrm{AE}$, and none of the ventral setae on tibia I is bipectinate. Actacarus pacificus has an idiosomal length of 235-282 $\mu \mathrm{m}$ (Australian specimens), the length of the GA relative to that of the $\mathrm{AE}$ is less than in $A$. nanus, the ventral setae on tibia I are apparently smooth.

\section{Distribution}

Southeastern Pacific (Chile, Robinson Crusoe Island), Northeastern Pacific (Hawaiian Islands), Sea of Japan (Hokkaido), Eastern Indian Ocean (Western Australia, Rottnest Island, Dampier). Intertidal to $10 \mathrm{~m}$.

\section{Subfamily Anomalohalacarinae Bartsch, 1985}

Genus Anomalohalacarus Newell, 1949

Anomalohalacarus dampierensis sp. nov. Figures $3 \mathrm{~A}-\mathrm{H}, 4 \mathrm{~A}-\mathrm{G}$

\section{Material Examined}

Holotype

Male, Dampier, 20 $39^{\prime} \mathrm{S}, 116^{\circ} 42^{\prime} \mathrm{E}$, Western Australia, Australia; sandy beach, coarse, unsorted sand in middle part of tidal slope, $0-3 \mathrm{~cm}$ sediment depth, 3 August 2000, coll. I. Bartsch (WAM T52097).

\section{Paratype}

Australia: Western Australia: 1 protonymph, same data as for holotype (WAM T52098).

\section{Etymology}

An adjective referring to the type locality Dampier.

\section{Diagnosis}

Idiosomal length $300 \mu \mathrm{m}$. AD and PD almost equal in length. PD undivided. Setae ds-5 lacking. Setae on epimera IV lacking. Anterior margin of male GA arched. GA with at least four pairs of pgs. P-2 with two setae. Tibia I with two short, bipectinate ventral spurs. Tibia I with eight setae, two of them spur-like. Tibiae II, III and IV each with pair of ventral setae which are slightly pectinate on tibiae III and IV but pectinate and slender on tibia II. One of the two setae on telofemur IV conspicuously stout.

\section{Description}

\section{Male}

Idiosoma. Length $300 \mu \mathrm{m}$; very slender, much longer than wide. Dorsal and ventral plates delicate. Membraneous integument faintly striated. Length of $\mathrm{AD} 57 \mu \mathrm{m}$, width $39 \mu \mathrm{m}$; with pair of gland pores in lateral margin and pair of $\mathrm{ds}-1$ posterior to gland pores (Figure 3A). PD undivided, its length $57 \mu \mathrm{m}$, width $30 \mu \mathrm{m}$; with pair of pores in posterior third of plate and small ds- 6 in posterior margin. $\mathrm{AD}$ and PD each with pair of gland pores. Setae ds- 1 to ds- 4 long, slender; ds- 1 inserted on $\mathrm{AD}, \mathrm{ds}-2$ and ds-3 within striated integument; ds- 5 not seen; ds- 6 very short, in posterior margin of $\mathrm{PD}$.

$\mathrm{AE}$ divided by striated integument into right and left half (Figure 3B). Length of AE $42 \mu \mathrm{m}$ (to camerostome). Each half with three setae and an epimeral pore. Long apodemes between epimera I and II. PE in posterior fourth of idiosoma. Each plate with one dorsal and two ventral setae; no seta in area representing epimeral plate IV. Anterior margin of GA broadly arched, with at least four pairs of perigenital setae (genital region obscured by legs III and IV and hence setae difficult to discern). Spermatopositor extending far beyond GA. Position of sgs not discernable in the single male available.

Gnathosoma. Very slender (Figure 3C), its length 

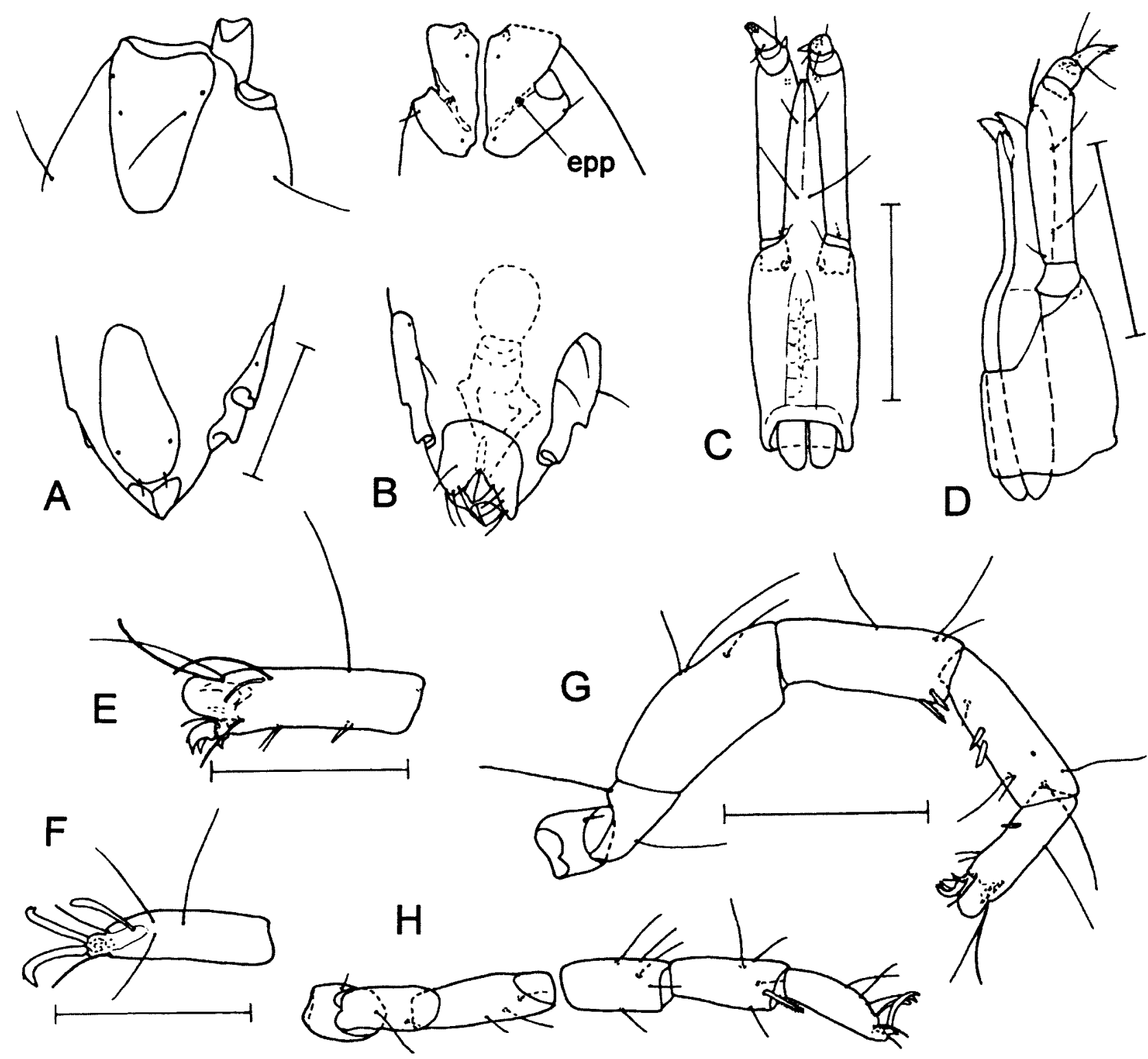

Figure 3 A-H, Anomalohalacarus dampierensis sp. nov., male. A, Anterior and posterior part of idiosoma, dorsal; B, AE, PE and GA, ventral; C, gnathosoma, ventral; D, gnathosoma, lateral; E, tarsus I, lateral; F, tarsus II, dorsal; G, leg I, medial; H, leg II, ventral and ventromedial. Scale $=50 \mu \mathrm{m}$ (epp, epimeral pore).

$87 \mu \mathrm{m}$, width $28 \mu \mathrm{m}$. Rostrum almost as long as gnathosomal base; with two pairs of long maxillary setae; apex with two pairs of minute rostral setae. P-2 with short, slender basal and stout distal seta (Figure 3D). P-3 with large medial spine. P-4 with three setae in basal whorl; apex with minute ventral and lateral seta and flattened dorsal seta.

Legs. Leg I longer and wider than the other legs. Genu and tibia I almost equal in length and shorter than telofemur I. Both lateral and medial fossa membrane of tarsus I large. Tarsi II to IV lack prominent membranes. Leg chaetotaxy (solenidia and pas included, famulus excluded): leg $I, 1,2,3$, 5, 8, 9; leg II, 1, 2-3, 3, 5, 5, 6; leg III, 1, 1, 2, 3, 5, 5; leg IV, 0, 0, 2, 3, 5, 5. Dorsal seta of basifemur I conspicuously long and stout (Figure 3G). Genu I with two short, slightly bipectinate spurs, inserted adjacent and ventromedially. Tibia I with two ventral spurs; most of dorsal setae slender except rather thick distolateral seta. Tarsus I with three ventral setae, one spur-like, two short and slender. Dorsal and dorsomedial fossary seta slender, dorsolateral fossary seta and dorsolateral solenidion conspicuously thick (Figure 3E). Famulus slender, pressed to lateral fossa membrane; its length $8 \mu \mathrm{m}$. Genua II to IV with slender ventral setae. Tibiae II to IV each with pair of ventral setae; on tibia II one of these setae pectinate and one slender (Figure $3 \mathrm{H}$ ), on tibiae III and IV both setae equal-sized, with very delicate pectination. Tarsus II with large, claviform solenidion in dorsolateral position (Figure $3 \mathrm{~F}$ ); the three dorsal setae slender. Tarsi I to IV with pair of pas singlets. Telofemora III and IV each with two dorsal setae, on telofemur IV one of these setae stout.

Paired claws of tarsus I short, with basiventral 

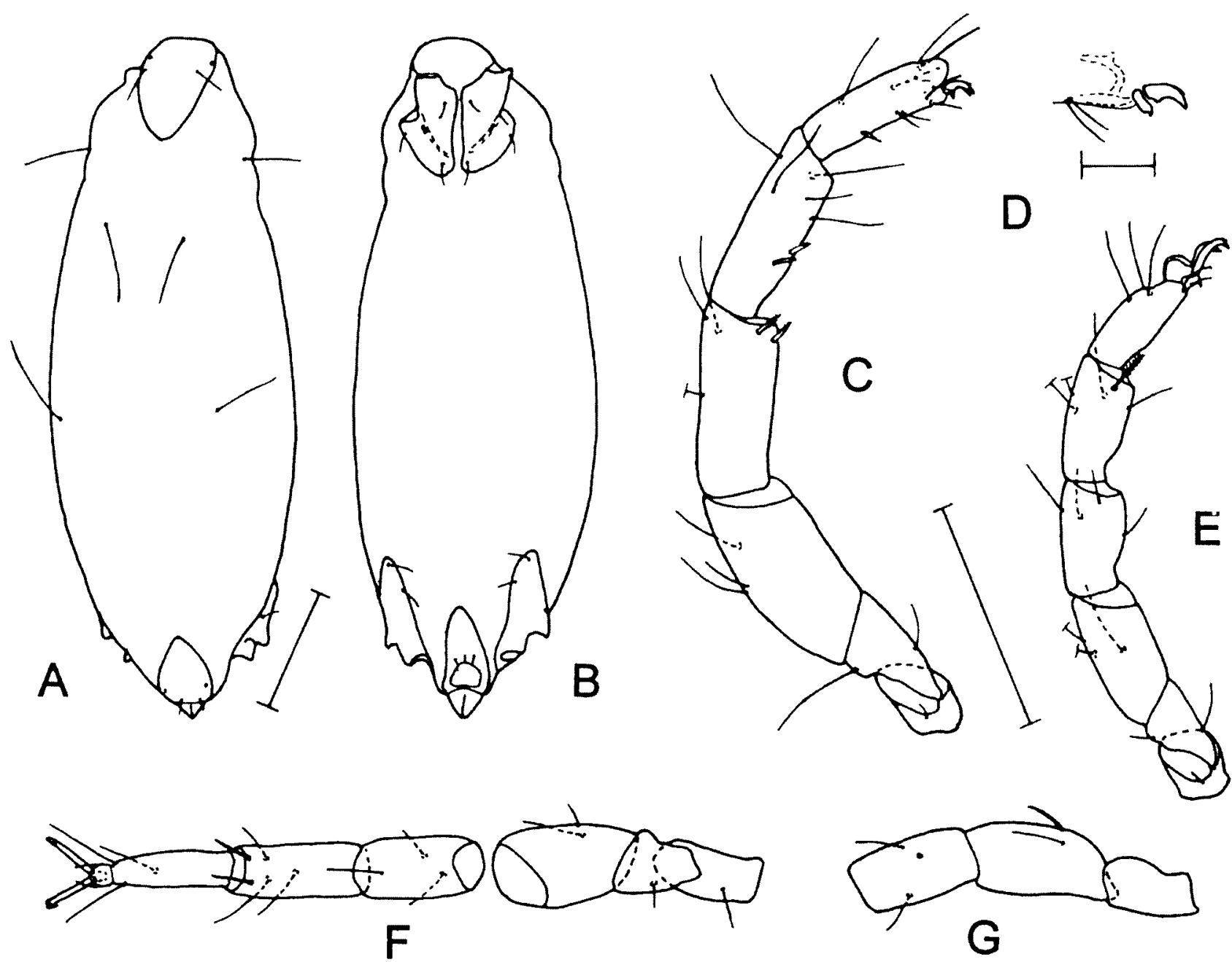

Figure 4 A-G, Anomalohalacarus dampierensis sp. nov., protonymph. A, Idiosoma, dorsal; B, idiosoma, ventral; C, leg I, medial; D, tip of tarsus I with claw; E, leg II, medial; F, leg III, ventral; G, trochanter, femur, genu IV. Scale = $50 \mu \mathrm{m}(\mathrm{A}-\mathrm{C}, \mathrm{E}-\mathrm{G})$, scale $=10 \mu \mathrm{m}(\mathrm{D})$.

process (as in protonymph, Figure 4D). Paired claws of tarsi II to IV with accessory process but without pecten. Central sclerite with minute clawlike process.

\section{Protonymph}

Idiosomal length $268 \mu \mathrm{m}$, width $100 \mu \mathrm{m}$. Arrangement of plates and setae as illustrated (Figure $4 \mathrm{~A}$ and $\mathrm{B}$ ). $\mathrm{AE}$ as in male with three pairs of setae, PE with one dorsal and two ventral setae. Gnathosoma slender, length $80 \mu \mathrm{m}$, width $25 \mu \mathrm{m}$, number and arrangement of setae same as in adults. Leg chaetotaxy (with solenidia and pas): leg I, 1, 2, $3,5,7,9$ (Figure 4C); leg II, 1, 2, 3, 4, 5, 6 (Figure 4E); leg III, 1, 1, 2, 3, 5, 5 (Figure 4F); leg IV, 0, 0+2 (basi+ telofemur), 3, 5, 5. Genu I with two spur-like, pectinate setae. Tibia I with two spur-like setae. Tibiae II with one slender and one pectinate seta; tibiae III and IV each with two faintly bipectinate setae. One of dorsal setae on telofemur IV stout (Figure 4G).

\section{Remarks}

Most species of the genus Anomalohalacarus are known from the North Atlantic and the Mediterranean. There is a single species from the western Pacific, from Japan, and three from the Indian Ocean, two from Western Australia and one species of unknown identity from the Bay of Bengal (Abé, 1996; Bartsch, 1976a, b, 1981b, 1985a, 1991a, 1993; Monniot, 1967; Morselli and Mari, 1981, 1982, 1989; Rao, 1970).

The idiosoma and dorsal and ventral plates are similarly shaped in the males of the two Australian species, A. macellus Bartsch, 1993, from Rottnest Island, and A. dampierensis. The two species differ in the setation of the legs. Tibia I of A. dampierensis bears eight setae, two of them are spur-like, in contrast, tibia I of A. macellus has 10 setae. The protonymph of $A$. dampierensis has a longer genital plate than that nymph of $A$. macellus.

Anomalohalacarus biformis Abé, 1996, from Hokkaido, Japan (Abé, 1996), has 10 setae on tibia I. 
The species is easily separated from the two Australian ones by the three ventral bristle-like setae on tibiae II and III.

Fourteen species have been described from the North Atlantic and adjacent basins. Two species, Anomalohalacarus anomalus (Trouessart, 1894) and A. litoralis Bartsch, 1981, differ from the others in that the idiosomal integument is very prominently striated (cf. Monniot, 1967: figure 1C), the P-2 bears two large setae, one in the basal, one in the distal portion, and tibia I three ventral setae (two spurlike, one seta-like) in the basal half of the segment. In the other North Atlantic species, the striae of the integument are rather delicate, the P-2 bears a single seta which is slender and inserted near the base of that segment, and in the basal portion of tibia I there are one or two setae which are either setiform or seti- and spiniform. Except for A. marcandrei Monniot, 1967, the PD of adult North Atlantic species is divided into a right and left half.

The three species from the Indo-Pacific region differ from those of the North Atlantic and its adjacent basins by (1) absence of the ds- 5 and (2) absence of the posterior pair of setae on the PE (generally attributed to epimeron IV). The PD is undivided, the idiosomal integument delicately striated, P-2 bears two setae, the basal seta is short and slender, similar to that of the majority of the North Atlantic species, the posterior seta is stout, resembling that seta of $A$. anomalus and $A$. litoralis. In the basal portion of tibia I there are more than two ventral setae.

\section{Distribution}

Indian Ocean (Western Australia, Dampier). Intertidal.

\section{Subfamily Halacarinae Viets, 1927}

Genus Arhodeoporus Newell, 1947

Arhodeoporus corallicolus Otto, 2000 Figures $5 \mathrm{~A}-\mathrm{F}, 6 \mathrm{~A}-\mathrm{F}$

Arhodeoporus corallicolus Otto, 2000g: 5-7, figure 4.

\section{Material Examined}

Australia: Western Australia: 1 female, 1 male, Dampier Archipelago, Enderby Island, West of Rocky Head, $20^{\circ} 32.1^{\prime} \mathrm{S}, 116^{\circ} 26.7^{\prime} \mathrm{E}$, sponge garden, 2-13 m, unsorted sandy deposits, 3 August 2000, coll. C. Bryce (WAM T52099 and T52100).
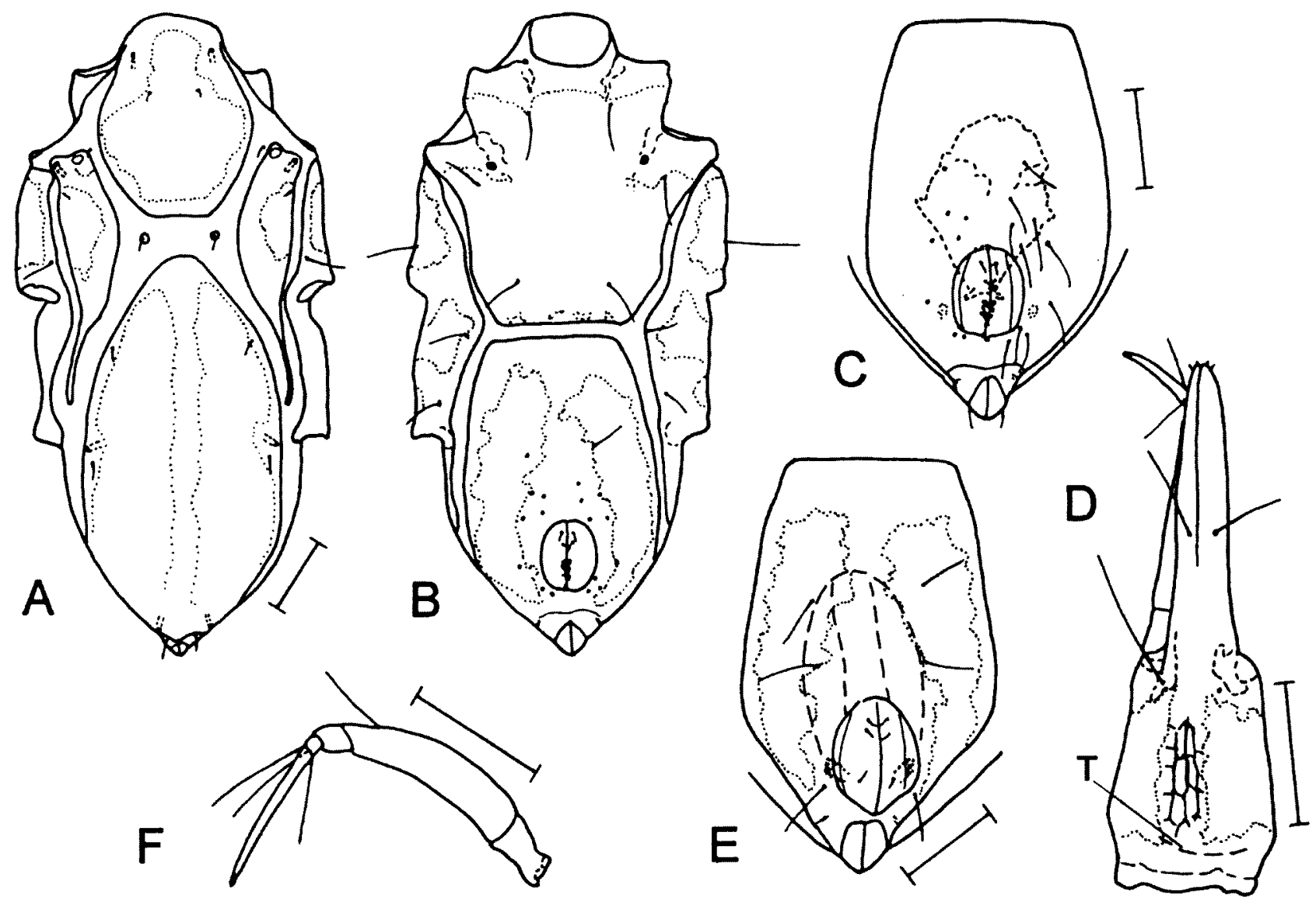

Figure 5 A-E. Arhodeoporus corallicolus Otto, 2000. A, Idiosoma, dorsal, male; B, idiosoma, ventral, male; C, genitoanal plate, male; D, gnathosoma, ventral, male; E, genitoanal plate, female; F, palp, lateral, male. Scale $=50 \mu \mathrm{m}(\mathrm{T}$, tectum). 


\section{Diagnosis}

Idiosomal length $400-411 \mu \mathrm{m}$. Surface of plates smooth but integument pierced by numerous canaliculi. Outline of such porose areolae as illustrated (Figure 5A and $\mathrm{B}$ ). OC with long tail and one small cornea and, beneath, small spots of eye pigment. Anterior margin of PD ovate. Each of the four pairs of gland pores with a small tube. Pair of ds-2 within striated integument; ds-3 on small platelets; ds -5 just posterior to gland pore. Punctation of AE coarser than that of dorsal plates and GA. Opposing margins of $A E$ and GA truncate. AE with pair of epimeral pores. PE with one dorsal and three ventral setae. Female GA with three pairs of pgs; genital sclerites with three pairs of sgs; two pairs of internal genital acetabula. Ovipositor extending slightly beyond the level of anterior pair of pgs (Figure 5E). Male GA with 17 pgs; genital sclerites with five pairs of sgs and a slightly projecting posterior cone (Figure 5C). Spermatopositor extending well beyond anteriormost pair of pgs. Gnathosoma slender, almost three times longer than wide and 0.44 of idiosomal length. Rostrum distinctly longer than gnathosomal base (Figure 5D). The latter with marginal porose areolae. Rostral trough long; truncate tectum in basal portion of gnathosomal base (Figure 5D). Palps slender (Figure 5F). Basiand telofemora II to IV flattened; telofemora II to IV about twice as long as high; basifemora dorsally slightly projecting. Tibiae slender, cylindrical. Height of telofemora II to IV 1.8-2.0 times that of relevant tibiae. Tibia I longer than telofemur I, tibiae of following legs as long as or shorter than telofemora. Leg chaetotaxy (solenidia included, pas excluded): $\operatorname{leg} \mathrm{I}, 1,2,3,4,8,7$ (Figure 6A); leg

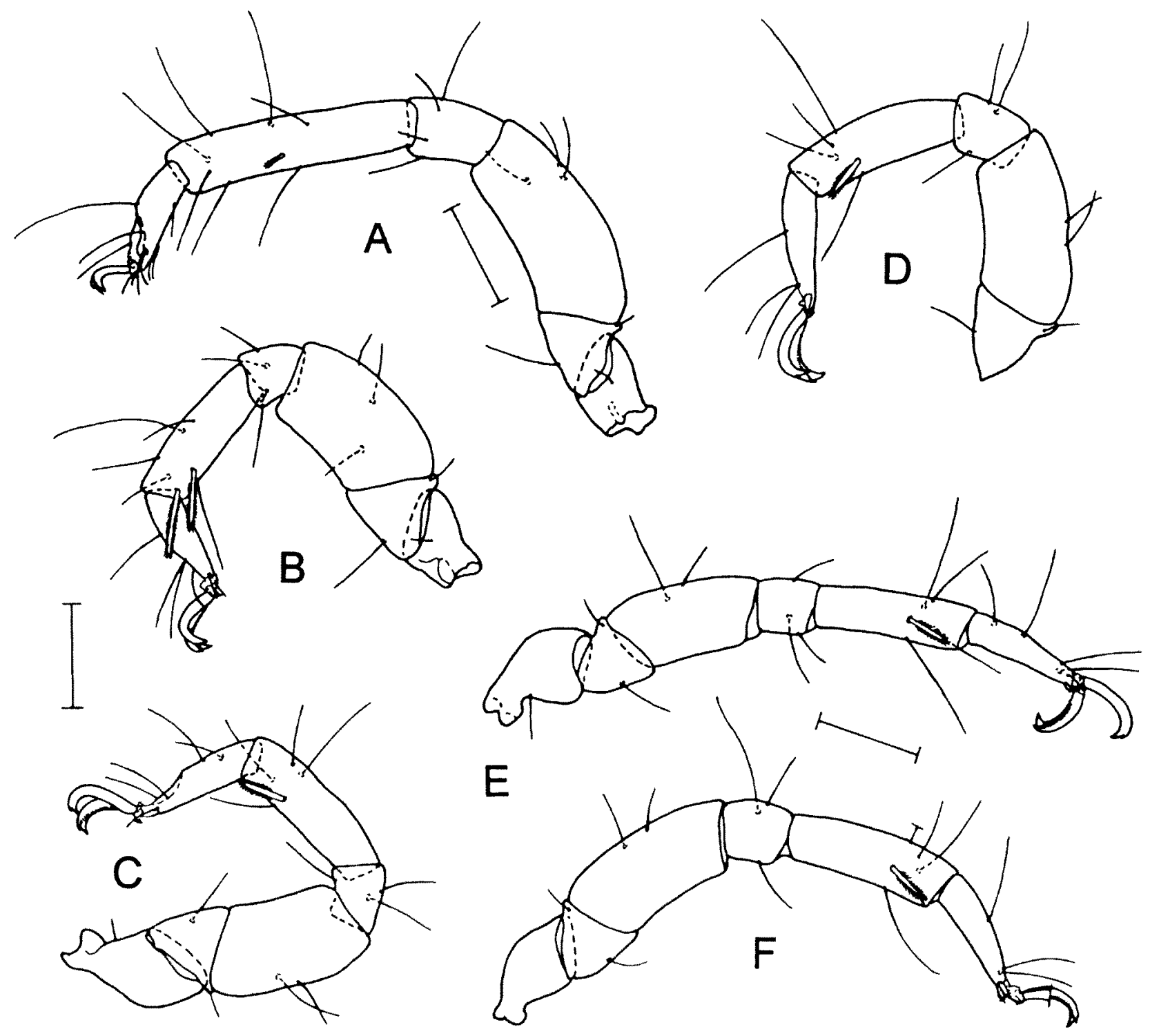

Figure 6 A-F. Arhodeoporus corallicolus Otto, 2000, male. A, Leg I, medial; B, leg II, medial; C, leg III, medial; D, basifemur to tarsus IV, medial; E, leg III, medial; F, leg IV, medial. A-D, male from Dampier; E and F, paratype from Great Barrier Reef. Scale $=50 \mu \mathrm{m}$. 
II, 1, 2, 3, 4, 7, 4 (Figure 6B); leg III, 1, 2, 2, 3, 5, 4 (Figure 6C); leg IV, 0, 2, 2, 3, 5, 3 (Figure 6D). Ventral flank of tibia I with one short, pectinate and three long, smooth setae. Tibiae II to IV with 2, 1, 1 bipectinate and 1, 1, 1 smooth and slender seta. Tarsus I short, less than half length of tibia I. Tarsi I and II with slender pas; tarsus III with slender medial and short, wide lateral pas; tarsus IV with pair of short and wide pas. Claws with accessory process and pecten; tines of pectines very short (seen only at high magnification and oil immersion).

\section{Remarks}

The specimens from the Dampier Archipelago have conspicuously flattened telofemora II to IV, their height is almost twice that of the tibiae. The height of the telofemora of the Great Barrier Reef specimens (Otto 2000g: figure $4 \mathrm{f}$ and present paper: Figure $6 \mathrm{E}$ and $\mathrm{F}$ ) is less striking, 1.5-1.7. The fixative and the contraction of the muscles may influence the shape of the telofemora. The slight difference in the shape of the PD is expected to be within the variability of this character; the anterior portion of the holotype PD is broadly rounded (Otto $2000 \mathrm{~g}$ : figure 4a), that of the specimen from Dampier more slender (Figure 5A).

Species most similar to Arhodeoporus corallicolus are $A$. caudatus Otto, 2000, $A$. clypeatus Otto, 2000, A. lizardensis Otto, 2000, and A. psammophilus Bartsch, 1993, all from Australia, from the Great Barrier Reef, the Queensland Plateau and from Rottnest Island, off Perth (Otto, 2000g; Bartsch, 1993). Further species are $A$. mactanus Bartsch, 1991, from the Philippine Island Mactan, and A. longirostris Bartsch, 1981, from off the Isles Glorieuses, Mozambique Channel (Bartsch, 1981a, 1982, 1991b). Arhodeoporus corallicolus can be identified on the base of the combination of: OC with one cornea; $\mathrm{AE}$ and GA separated; punctation of $\mathrm{AE}$ coarser than that of the other plates; tibia I with short, delicately pectinate seta; basi- and telofemora flattened. An unique character is that the female genital sclerites bear three pairs of sgs, in contrast to two pairs of setae which is the most common state of this character.

Arhodeoporus corallicolus has very flattened telofemora. In general, the telofemora of halacarid mites are almost cylindrical, but in many species the legs bear large ventral lamellae, e.g. in species of the Copidognathus gibbus group (Bartsch, 1994b; Otto, 2000f). In $A$. corallicolus there are no such lamellae.

\section{Distribution}

Great Barrier Reef, northeastern Australia, and Dampier, northwestern Australia. Inhabitant of shallow water sandy deposits.

\section{Subfamily Copidognathinae Bartsch, 1983}

Genus Copidognathus Trouessart, 1888

Copidognathus meridianus Bartsch, 2003

Copidognathus meridianus Bartsch, 2003b: $x \mathrm{x}-\mathrm{xx}$, figures $1 \mathrm{~A}-\mathrm{H}, 2 \mathrm{~A}-\mathrm{H}, 3 \mathrm{~A}-\mathrm{F}$.

\section{Material Examined}

Australia: Western Australia: 3 females, 1 male, Dampier, $20^{\circ} 39^{\prime} \mathrm{S}, 116^{\circ} 42^{\prime} \mathrm{E}$, unsorted sand in midand upper tidal shore, 31 July 2000 and 1 August 2000, coll. I. Bartsch (WAM T45195-T45198); 1 female, north of Cape Preston, 40 Mile Beach, coarse unsorted sediment, upper tidal shore, 6 August 2000, coll. I. Bartsch (WAM T45199).

\section{Diagnosis}

Idiosomal length 360-385 $\mu \mathrm{m}$. Dorsal plates almost uniformly ornamented with small pits arranged within polygons. AD with three delicately raised areolae. $P D$ without prominent costae. $O C$ with minute cornea. PD with pairs of pores at the level and posterior to ds-5; each pore with large internal gland. Female GA with four pairs of pgs; male GA with 15-16 widely scattered pairs of pgs. Length of gnathosoma almost one third of that of idiosoma. Length:width ratio of gnathosoma 1:0.7; rostrum triangular, about as long as gnathosomal base and extending just beyond P-2. Tectum truncate. Leg chaetotaxy (solenidia and pas included): $\operatorname{leg}$ I, 1, 2, 5, 4, 7, 11; leg II, 1, 2, 5, 4, 7, 8; leg III, 1, 2, 2, 3, 5, 5; leg IV, 0, 2, 2, 4, 5, 5. Tibiae II to IV with 2, 1, 1 bipectinate setae. Tarsi I to IV with 4, 4, 3, 3 dorsal setae (solenidia included). Pectines of claws II to IV with delicate tines.

\section{Remarks}

This rather large-sized psammophilous Copidognathus species can be separated from congeners by the unique combination of (1) dorsal plates almost uniformly ornamented and (2) genu IV with four setae.

\section{Distribution}

Tropical Western Australia, Dampier. Present in sandy deposits, in mixed coarse and fine sand. In the Dampier area, this species dominated the intertidal psammophilous halacarid fauna.

\section{Subfamily Lohmannellinae Viets, 1927}

\section{Genus Scaptognathides Monniot, 1972}

\section{Scaptognathides hawaiiensis Bartsch, 1988 Figure 7A-E}

Scaptognathides hawaiiensis Bartsch, 1988: 221, 222, figures 27-30; Bartsch, 1991c: 59, figure 1A-H. 

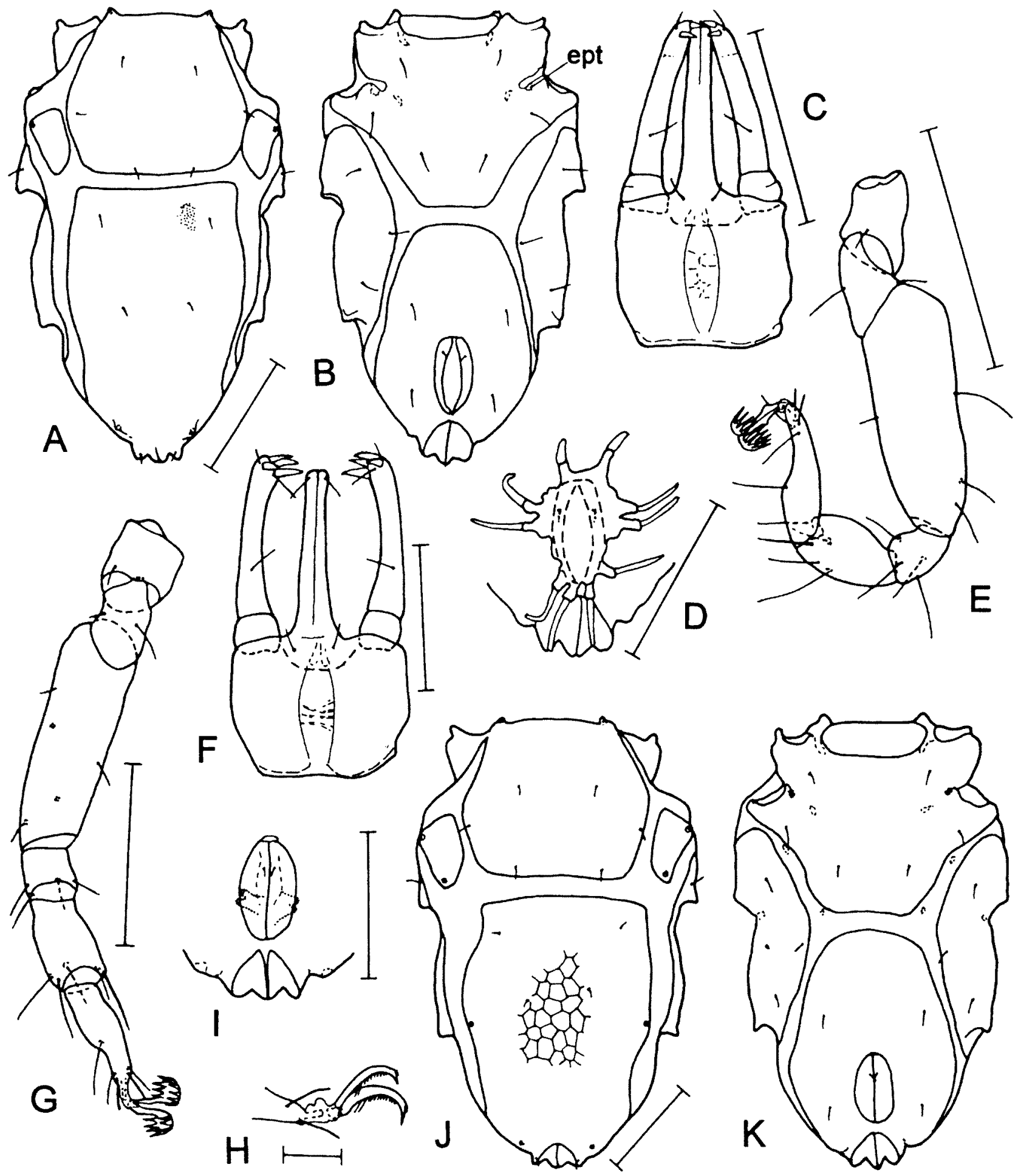

Figure 7 A-D. Scaptognathides hawaiiensis Bartsch, 1988, female. A, Idiosoma, dorsal; B, idiosoma, ventral; C, gnathosoma, ventral; D, ovipositor; E, leg I, medial. (ept, epimeral tube). F-K. Scaptognathides ornatus Bartsch, 1988, female. F, gnathosoma, ventral; $G$, leg I, ventral; H, tip of tarsus II, medial; I, genital opening; J, idiosoma, dorsal; $K$, idiosoma, ventral. Scale $=50 \mu \mathrm{m}(\mathrm{A}-\mathrm{G}, \mathrm{I}-\mathrm{K})$, scale $=10 \mu \mathrm{m}(\mathrm{H})$.

\section{Material Examined}

Australia: Western Australia: 3 females, Dampier, sandy beach, coarse, unsorted sand, lower part of tidal slope, $2-15 \mathrm{~cm}$ sediment depth, 4 August 2000, coll. I. Bartsch (WAM T52101 and T52102).

\section{Diagnosis}

Idiosomal length $170-180 \mu \mathrm{m}$. Dorsal and ventral plates minutely pitted. $\mathrm{AD}, \mathrm{OC}$ and $\mathrm{PD}$ each with one pair of gland pores (Figure 7A). Pairs of ds-1, ds- 2 and ds- 3 on AD, ds- 4 and ds- 5 on PD, adanal setae on anal valves. AE with three pairs of setae 
and pair of small epimeral tubes (Figure 7B). GA with two pairs of pgs, genital sclerites with one pair of sgs. Gnathosomal length $0.44-0.47$ times of that of idiosoma. Margin of tectum truncate. Rostrum slightly longer than gnathosomal base (Figure 7C). Two of the four apical palpal spines pectinate. Leg I somewhat longer and considerably more stout than following legs. Length of legs I and IV about 0.75 of that of idiosoma. Leg chaetotaxy (very short solenidia excluded, pas included): legs I and II, 1, 2 , 4, 4, 5, 5; legs III and IV , 1, 2, 2, 3, 5, 5. Length:height ratio of telofemora II to IV about 2.2-2.3. Paired claws of tarsus I with large, umbrella-like arranged tines (Figure 7E). Pectines of claws of tarsi II to IV seen only at higher magnification; basalmost tine twice the length of the other very delicate tines.

\section{Supplementary notes}

Ovipositor with 10 pairs of delicately sclerotized, lamellar genital spines (Figure 7D).

\section{Remarks}

The PD of Scaptognathides hawaiiensis bears a single pair of gland pores situated near the posterior margin of the plate. In the other Australian species, the PD has two pairs of gland pores, one pair about the level of insertion of leg IV, the other pair near the posterior margin, similar to S. hawaiiensis.

Records of S. hawaiiensis are from the Hawaiian Archipelago, Hong Kong and northwestern Australia. There are small differences in the shape of the female GA, with the anterior margin oviform in the individuals from the Hawaiian Archipelago (Bartsch 1988: figure 28) but almost truncate in those from the Dampier area. Considering the delicateness of the plates, which easily can be deformed, the differences mentioned are thought to be negligible.

\section{Distribution}

Northeastern Pacific (Hawaiian Islands), South China Sea (Hong Kong), Eastern Indian Ocean (Western Australia, Dampier). Intertidal sandy deposits.

\section{Scaptognathides ornatus Bartsch, 1988} Figure $7 \mathrm{~F}-\mathrm{K}$

Scaptognathides ornatus Bartsch, 1988: 222-224, figures 31-39.

\section{Material Examined}

Australia: Western Australia: 1 female, Dampier, $20^{\circ} 39^{\prime} \mathrm{S}, 116^{\circ} 42^{\prime} \mathrm{E}$, sandy beach, coarse, unsorted sand in lower part of tidal slope, $2-15 \mathrm{~cm}$ sediment depth, 4 August 2000, coll. I. Bartsch (WAM T52103).

\section{Diagnosis}

Idiosomal length $217 \mu \mathrm{m}$. Dorsal plates reticulated (Figure 7J). AD with one pair of pores, $O C$ and PD each with two pairs of gland pores. Pair of ds-1, ds-2 and ds-3 on AD, ds- 4 near anterolateral corners of PD, ds-5 situated in middle of plate anterior to the level of pair of glp-4. Marginal areas of ventral plates faintly reticulated, ventral portions punctate. GA with two pairs of pgs (Figure 7K) and two pairs of internal genital acetabula (Figure 7I), its genital sclerites with one pair of sgs. Length of gnathosoma 0.48 times that of idiosoma. Tectum concave, median margin truncate. Rostrum somewhat longer than gnathosomal base (Figure 7F). Two of apical palpal spines pectinate. Legs I and IV almost 0.75 of idiosomal length. Length of genu I about 0.6 and 0.2 times that of tibia and telofemur I, respectively. Telofemora II to IV slender, almost three times longer than high. Leg chaetotaxy (very short solenidia excluded): legs I and II, 1, 2, 5, 4, 5, 5; legs III and IV, 1, 2, 2, 3, 5, 5. Paired claws of tarsus I with long, umbrella-like arranged tines (Figure 7G); claws of tarsi II to IV with minute accessory process, pecten with tines, two basalmost tines enlarged (Figure $7 \mathrm{H}$ ).

\section{Remarks}

The two species, Scaptognathides ornatus and $S$. hawaiiensis, present in Dampier in the same beach, are easily separated even at low magnification; $S$. ornatus is larger, has reticulate dorsal plates and slender telofemora II to IV.

From Australian shores, six species of Scaptognathides are recorded, S. australis Bartsch, 1993, S. hawaiiensis, S. heraldensis Otto, 2000, S. ornatus, S. tomkinsae Otto, 2000, and S. undulatus Otto, 2000. Characters to identify adults (and assumedly nymphs as well are):

Scaptognathides australis: OC slender, at least four times longer than wide, and with a single gland pore; PD with two pairs of gland pores.

Scaptognathides hawaiiensis: the only species with a single pair of gland pores on OC and PD.

Scaptognathides heraldensis: $\mathrm{OC}$ with one gland pore, PD with two pairs of pores; in contrast to S. australis, the $\mathrm{OC}$ are rhomboid, about twice as long as wide.

Scaptognathides ornatus: both OC and PD with two pairs of gland pores. Telofemora II to IV slender; tarsus III with three dorsal setae.

Scaptognathides tomkinsae: PD with two pairs of gland pores; $O C$ with a single pore, its posterior edge with a minute seta instead of a gland pore.

Scaptognathides undulatus: both $\mathrm{OC}$ and PD with two pairs of gland pores; tarsus III with four dorsal setae, instead of three as present in the other species. 


\section{Distribution}

Northeastern Pacific (Hawaiian Islands), Eastern Indian Ocean (Western Australia, Dampier). Intertidal.

\section{Genus Scaptognathus Trouessart, 1889}

\section{Scaptognathus exquisitus Otto, 2000} Figure 8A-E

Scaptognathus exquisitus Otto, 2000b: 539-543, figure 4.

\section{Material Examined}

Australia: Western Australia: 1 female, Enderby Island, West of Rocky Head, 20 $32.1^{\prime} \mathrm{S}, 116^{\circ} 26.7^{\prime} \mathrm{E}$, sponge garden, 2-13 $\mathrm{m}$, unsorted sandy deposits, 3 August 2000, coll. C. Bryce (WAM T52104).

\section{Diagnosis}

Idiosomal length $210 \mu \mathrm{m}$. Dorsal and ventral plates pitted, $A D$ with the pits arranged within polygons (Figure $8 \mathrm{~A}$ ). AD very wide, posterior margin arched. OC small, rounded. Anterior margin of PD truncate. AE wider than long, with large epimeral pores and circular markings. PE with funnel-like structures anterior to insertion of legs III and IV (Figure 8A and D). Female GA bipartite; posterior portion with two pairs of pgs (Figure 8B); genital sclerites with single pair of sgs. Gnathosoma almost twice as long as wide; its length 0.79 of that of idiosoma. Spatula-shaped rostrum shorter than gnathosomal base (Figure 8C). Legs slender; leg I 0.7 of idiosomal length. Lateral flanks of basi- and telofemora with small, deep foveae. Leg chaetotaxy (solenidia, famuli and pas excluded; bipectinate setae in roman numerals): $\operatorname{leg}$ I, 1, 1, 4+II, 3+II, 4+V, $4+\mathrm{I}$ (Figure 8E); leg II, 1, 1, 5, 3+I, 3+II, 3+I; leg III, 1, 1, 2, 3, 3+III, 3; leg IV, 1, 1, 2, 3, 3+III, 3. Tarsus I with 'hollow' claviform solenidion and solid, digitiform famulus. On either side of tarsi I and II one setiform and one distinctly shorter pas. Tarsus III with pair of setiform pas, medial pas with adjacent short seta. Tarsus IV with pair of small, setiform pas. Claws with small accessory process, else smooth. Central sclerite without dent-like process.

\section{Supplementary notes}

PE with funnels anterior to insertion of legs III and IV (Figure 8D).

\section{Remarks}

The individual in Otto (2000b: figure 4A, B) shows much wider areas between the dorsal and ventral plates than are present in the specimen from the
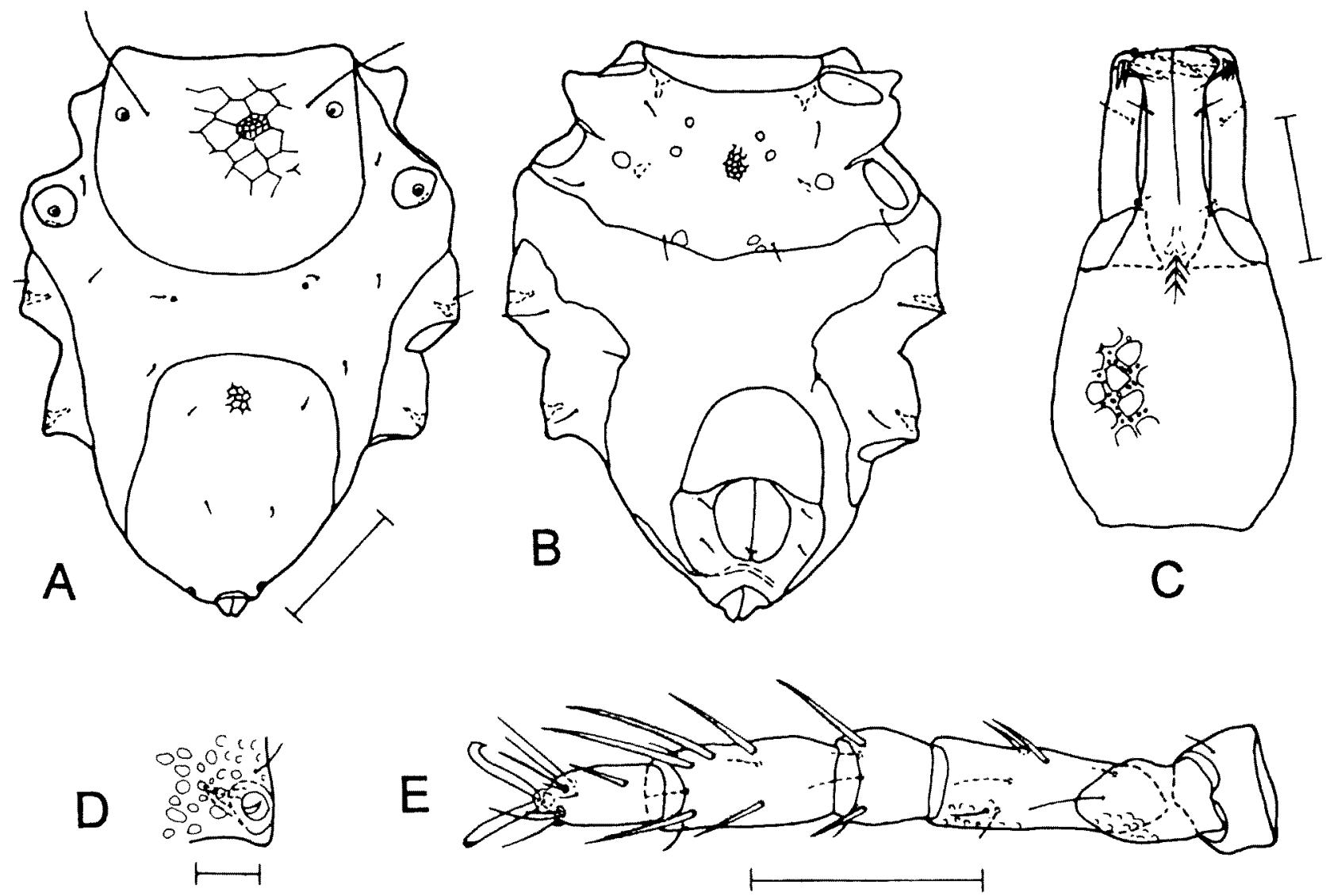

Figure 8 A-E. Scaptognathus exquisitus Otto, 2000, female. A, Idiosoma, dorsal; B, idiosoma, ventral; C, gnathosoma, ventral; $D$, epimeral plate $I I I$ anterior to insertion of leg III, with funnel shaped structure; $\mathrm{E}$, leg I, ventral. Scale $=50 \mu \mathrm{m}(\mathrm{A}-\mathrm{C}, \mathrm{E})$, scale $=10 \mu \mathrm{m}(\mathrm{D})$. 
Dampier Archipelago. Such a difference is common within ovigerous halacarid females, depending on the number and size of eggs. The difference in the length:width ratio of the gnathosoma (0.66 in the specimen from the Great Barrier Reef vs 0.79 in the one from Dampier) most likely is due to compression of the holotype.

Marginal cavities on the PE, anterior to the insertions of legs III and IV, have not been described before. They are also present in two paratype females (Zoological Museum in Hamburg A57/00) from the Great Barrier Reef.

\section{Distribution}

Scaptognathus exquisitus seems to be widespread along the coast of tropical Australia; records are from eastern Australia, from 19 to $14^{\circ} \mathrm{S}$, and western Australia, at $20^{\circ} \mathrm{S}$, from sandy deposits at a depth range of 0.5 to $10 \mathrm{~m}$.

\section{Subfamily Simognathinae Viets, 1927}

Genus Simognathus Trouessart, 1889

Simognathus platyaspis Otto, 2000 Figure 9A-E
Simognathus platyaspis Otto, 2000a: 519-521, figures 14A-D, 15A-D.

\section{Material Examined}

Australia: Western Australia: 1 female, Burrup Peninsula, Watering Cove, $20^{\circ} 35^{\prime} \mathrm{S}, 116^{\circ} 58^{\prime} \mathrm{E}$, coral block, low water edge, 1 August, 2000, coll. I. Bartsch (WAM T52105).

\section{Diagnosis}

Idiosomal length $315 \mu \mathrm{m}$, width $170 \mu \mathrm{m}$. Dorsal plates uniformly foveate, integument delicately punctate. Posterior two-third of $\mathrm{AD}$ with brown pigmentation. $A D$ longer than $P D$ (Figure 9A). OC triangular. $\mathrm{AD}$ with hyaline lens, $\mathrm{OC}$ with cornea. Ventral plates almost uniformly foveate except for (1) a portion immediately posterior to camerostome, (2) anterior portion of GA and (3) around GO (Figure 9B). GA with four pairs of pgs. Adanal setae in ventral position. Ventral flank of gnathosoma foveate. Triangular lamella forming a tectum (Figure $9 \mathrm{C}$ ). Second palpal segment with ventral protuberance and one long seta (Figure 9D). Tibiae club-shaped. Leg chaetotaxy (solenidia omitted, pas included): leg I, 1, 2, 2, 4, 5, 6; leg II, 1, 2, 3, 4, 5, 6; legs III and IV, 1, 1, 2, 3, 5, 5. Ventral seta of tibia I basally wide, with apophysis, then tapering (Figure
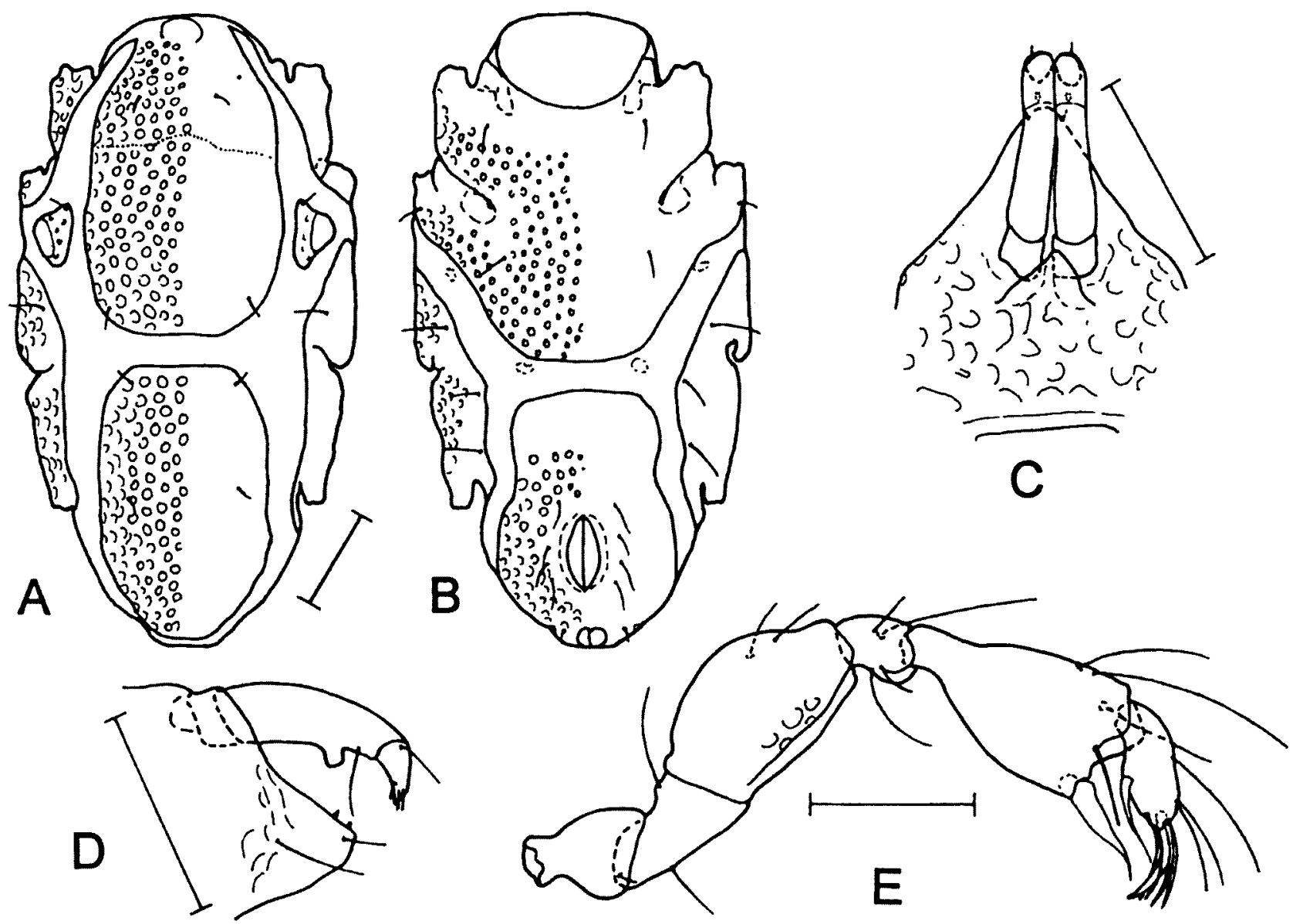

Figure 9 A-F. Simognathus platyaspis Otto, 2000, female. A, Idiosoma, dorsal (stippled line along margin of brown pigmentation); B, idiosoma, ventral; C, part of gnathosoma, dorsal; D, part of gnathosoma, lateral; D, leg I, medial. Scale $=50 \mu \mathrm{m}$. 
9E). Pair of ventral spines of tibiae II coarsely pectinate, that pair of spines on tibiae III and IV only slightly pectinate. Tarsi I and II each with three dorsal setae, one ventral seta and pair of single eupathid pas. Tarsi III and IV each with three dorsal setae, one ventral seta and medial pas. Tarsus I with large median claw and slender paired claws. Paired claws of tarsi II to IV with accessory process, else smooth; central sclerite with small process.

\section{Remarks}

Similarly shaped and pigmented plates and the same outline of palps and tibiae are present in $S$. maculatus Bartsch, 1994, S. specialis Otto, 2000, S. versicolor Otto, 2000, and S. xandarus Otto, 2000, all from Australia, in S. glareus Bartsch, 1985 from New Zealand, in S. latitarsus Proches, 2002 from South Africa, in S. obtusus Newell, 1971 and S. subobtusus Newell, 1984 from off Chile, and in S. fuscus Viets, 1936, recorded from the Caribbean (Viets, 1936; Newell, 1971, 1984; Bartsch, 1985b, 1994a; Otto, 2000a; Proches 2002).

In the just mentioned Australian species, as also in $S$. latitarsus, the foveate ornamentation of the $\mathrm{AE}$ is restricted to the lateral margins, ventrally the plate is uniformly punctate. In contrast, in S. platyaspis the $\mathrm{AE}$ is almost uniformly foveate. Females of the three southern Pacific species, S. glareus, S. obtusus and S. subobtusus, have a small PD and the ds-4 are situated within the membraneous integument, whereas in $S$. platyaspis that pair of setae is on the PD. Moreover, in S. glareus and S. subobtusus the paired claws on tarsus I are much more stout than in S. platyaspis, and female $S$. obtusus have a shorter GA relative to the size of GO.

Simognathus fuscus, a species from Bonaire (Viets, 1936), resembles $S$. platyaspis in shape and ornamentation. Otto (2000a) used the length:width ratio of the $\mathrm{AD}$ for discrimination, a quotient that can be influenced by the mounting procedure. The paratype of S. platyaspis, housed in the Zoological Museum in Hamburg, Germany (ZMH A3/01), is squeezed and the holotype (not seen by the author) is suspected to be deformed, too. The length:width ratio of the $A D$ in the present specimen of $S$. platyaspis is 1.65 , that of the holotype of S. fuscus 1.69 , hence almost the same. The rostrum of $S$. fuscus is very short, about one fifth of the length of the gnathosoma, but one fourth in S. platyaspis.

\section{Distribution}

Tropical Australia, Great Barrier Reef, $1-6 \mathrm{~m}$, coarse sand and coral rubble (Otto, 2000a) and Dampier area (present record). Not bound to sandy deposits.

Simognathus salebrosus sp. nov. Figures $10 \mathrm{~A}-\mathrm{J}, 11 \mathrm{~A}-\mathrm{F}$

\section{Material Examined}

Holotype

Male, Burrup Peninsula, east coast, King Bay, $20^{\circ} 38^{\prime} \mathrm{S}, 116^{\circ} 45^{\prime} \mathrm{E}$, sandy tidal bank in a small river emptying into King Bay, Western Australia, Australia; 25 July 2000, coll. I. Bartsch (WAM T52106).

\section{Other Material Examined}

Australia: Western Australia: 1 female, Dampier, $20^{\circ} 39^{\prime} \mathrm{S}, 116^{\circ} 42^{\prime} \mathrm{E}$, sandy flat, lower part of tidal slope, 1 August 2000, coll. I. Bartsch (WAM T52107).

\section{Etymology}

Derived from Latin salebrosus, rough, uneven, because of the rough surface of the plates.

\section{Diagnosis}

Idiosomal length 364-398 $\mu \mathrm{m}$. AD and PD with delicate punctation, their surface uniformly foveate. AD longer than PD. OC elongate, covered by membraneous integument. $\mathrm{AE}$ and GA fused. Plates foveate apart from area representing anterior part of GA. AE with large marginal epimeral fossae. Area of epimera II and PE contiguous; lateral GA and posterior part of $\mathrm{PE}$ almost articulating. Female GA with four pairs of pgs. Male GA with three pairs of outlying pgs and 26 pgs arranged in a ring close around GO. Gnathosomal base dorsally and marginally foveate; with triangular lamelliform tectum. Palps short. Trochanter I large, with small cylindrical base. Tibia I widest in basal third, then evenly tapering. Posterior part of tibia I rotated relative to axis of the leg. Tarsus I short, 0.17 of length of tibia. Tarsi I to IV with $1,1,1,1$ ventral setae and 2, 2, 1, 1 pas, respectively. Pectines of claws of tarsi II to IV with numerous short tines.

\section{Description}

\section{Male}

Idiosoma. Male. Length $364 \mu \mathrm{m}$, width $189 \mu \mathrm{m}$. $\mathrm{AD}$ and $\mathrm{PD}$ with intense punctation and superficial foveae. Length of $\mathrm{AD} 167 \mu \mathrm{m}$, width $130 \mu \mathrm{m}$; anterior margin undulate due to foveae (Figure $10 \mathrm{~A})$, posterior margin truncate. $\mathrm{AD}$ with ds- 1 and ds-3 as illustrated. OC reduced to short, elongate sclerite which is covered by striae of membraneous integument; its length $22 \mu \mathrm{m}$, width $7 \mu \mathrm{m}$. PD slightly longer than $\mathrm{AD}$, its length $175 \mu \mathrm{m}$, width $130 \mu \mathrm{m}$; anterior margin truncate. Pairs of ds -4 and ds-5 slightly posterior to the level of insertions of legs III and IV, respectively. Pair of ds- 6 in marginal position.

Ventral plates evenly punctate and foveate; foveae absent posterior to camerostome, in an area representing anterior part of GA and around GO 

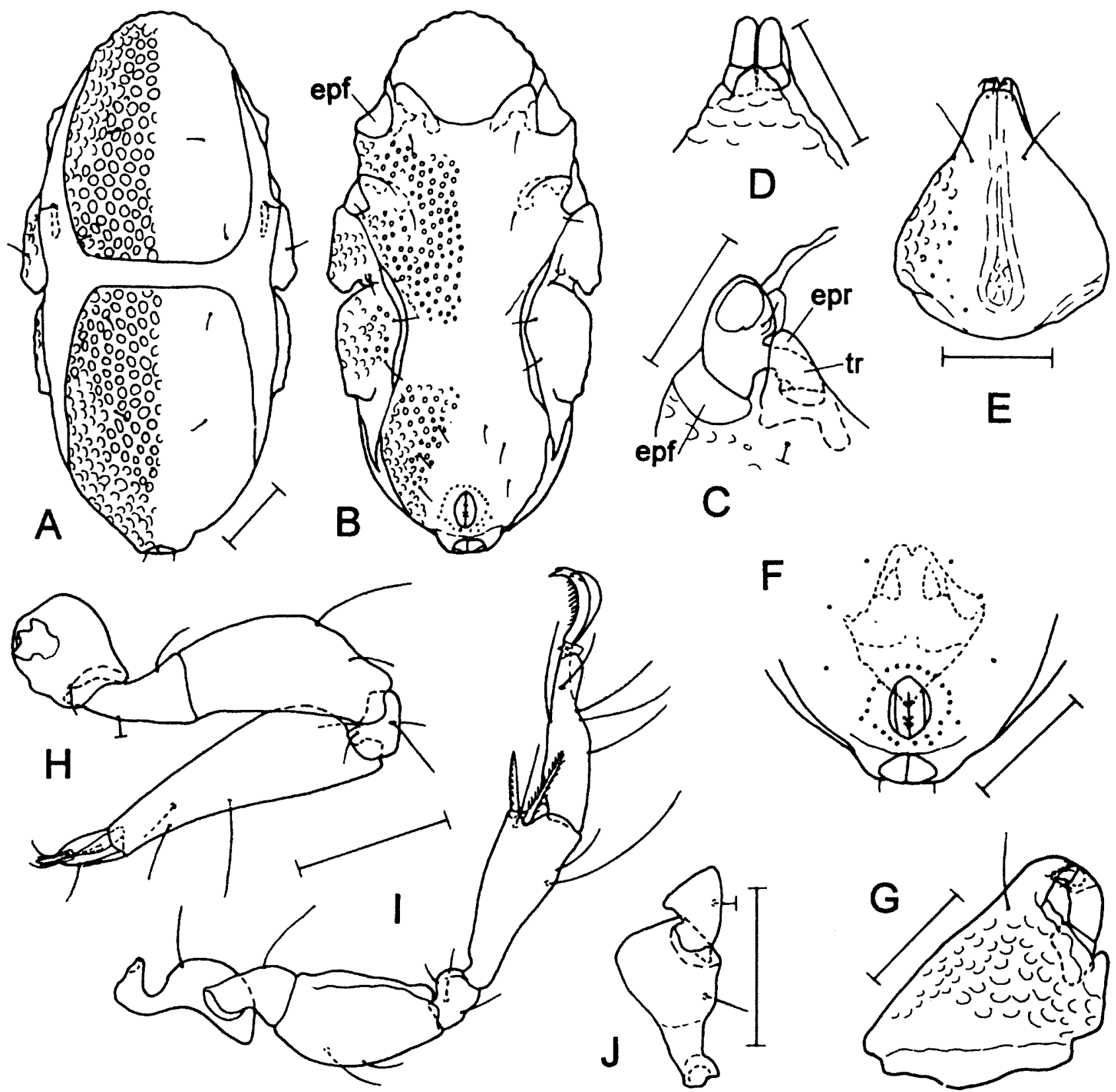

Figure 10 A-F. Simognathus salebrosus sp. nov. A, Idiosoma, dorsal, male; B, idiosoma, ventral, male; C, epimeral plate with fossa and trochanter I, female; D, tectum, male; E, gnathosoma, ventral, male; F, genital area, male; G, gnathosoma, lateral, female; $\mathrm{H}$, leg I, medial and ventral, male; I, leg III, medial (trochanter in ventral aspect), male; J, trochanter and basifemur III, medial, female. Scale $=50 \mu \mathrm{m}$ (epf, epimeral fossa; epr, epimeral process; tr, trochanter).

(Figure 10B). AE and GA fused to a ventral shield; its length $289 \mu \mathrm{m}$, width $164 \mu \mathrm{m}$. Epimera II and PE as well as posterior part of PE and lateral GA contiguous. Epimeral processes I to IV forming large lamellae. Anterior epimera with large marginal fossae lateral to insertions of legs I (Figure 10C) and II. AE with three pairs of setae and rather small epimeral vesicles. PE extending posteriad beyond insertion of leg IV. GO small, length $45 \mu \mathrm{m}$, width $27 \mu \mathrm{m}$, situated close to posterior margin of idiosoma. GA with three pairs of outlying pgs and $26 \mathrm{pgs}$ arranged in a ring close around GO. Genital sclerites with three pairs of sgs (Figure 10F).
Gnathosoma. Length $115 \mu \mathrm{m}$, width $99 \mu \mathrm{m}$. Gnathosomal base dorsally and marginally foveate (Figure 10G), median part of ventral flank almost smooth (Figure 10E). Dorsum with lamellar, triangular tectum (Figure 10D). Basal pair of maxillary setae long, distal pair short, slender. Palps short, three-segmented. Second segment with ventral seta but without protuberance; delicate incision may represent fusion between $\mathrm{P}-2$ and $\mathrm{P}-3$.

Legs I to IV rather similar in length. Base of trochanters I and II cylindrical, bent in an almost right angle to longitudinal axis of the legs (Figure 10C). Trochanters III and IV elongate, almost as 
long as telofemora. Telofemora III and IV longer than tibiae. Tibia I with cylindrical base, abruptly expanding at 0.28 (relative to length of tibia), then evenly tapering (Figure $10 \mathrm{H}$ ). Posterior portion rotated so that the ventral seta is in a medial position. Tibiae II to IV claviform (Figures 10I, 11B and C). Tarsus I very short, hardly longer than high, its median claw turned inward (Figure 11D and E). Tarsi II to IV at least three times longer than high. Leg chaetotaxy (solenidia omitted, pas included): $\operatorname{leg}$ I, 1, 2, 2, 4, 5, 6; leg II, 1, 2, 3, 4, 5, 6; legs III and IV, $1,1,2,3,5,5$. Ventral spine of tibia I stout, bluntly ending, without basal apophysis (Figure 11D); medial seta slender, flagelliform. Tibiae II to IV with pair of wide, roughly bipectinate ventral setae. Tarsi I to IV with three dorsal fossary setae; on tarsus I dorsomedial fossary seta shorter than dorsolateral one; on tarsi II to IV paired fossary setae delicately serrate. Tarsi I to IV each with long ventral seta, that seta on tarsus I basally wide, then tapering, on tarsi II to IV ventral seta delicately serrate. Tarsi I and II each with pair of pas, tarsi III and IV with medial pas. Solenidion of tarsus I setiform, famulus lamellar. Solenidion of tarsus II setiform, situated on inside of medial fossa membrane (Figure 11F).
Tarsus I with median claw and very slender paired claws, these claws smooth. Paired claws of tarsi II to IV large, with accessory process and pectines; central sclerite minute, without distinct claw-like process.

\section{Female}

Dorsal aspect resembling that of male. $\mathrm{AE}$ and GA fused. GA with four pairs of pgs (Figure 11A).

\section{Remarks}

Simognathus salebrosus is strikingly similar to $S$. abnormalus Otto, 2000 and S. scutatus Bartsch, 1993, species recorded from the Great Barrier Reef, Queensland and Rottnest Island, Western Australia, respectively (Otto, 2000a; Bartsch, 1993), the three species have a ventral shield, short tarsus I and a short palp which lacks a protuberance. S. scutatus is easily distinguished from the others because all ventral plates are fused, both in the female and male, and its tibia I is almost equal in height for most of its length. In contrast to males of $S$. abnormalus, which bear two pairs of outlying setae, the single male of $S$. salebrosus has three pairs of such setae. The female GA and PE of S. salebrosus
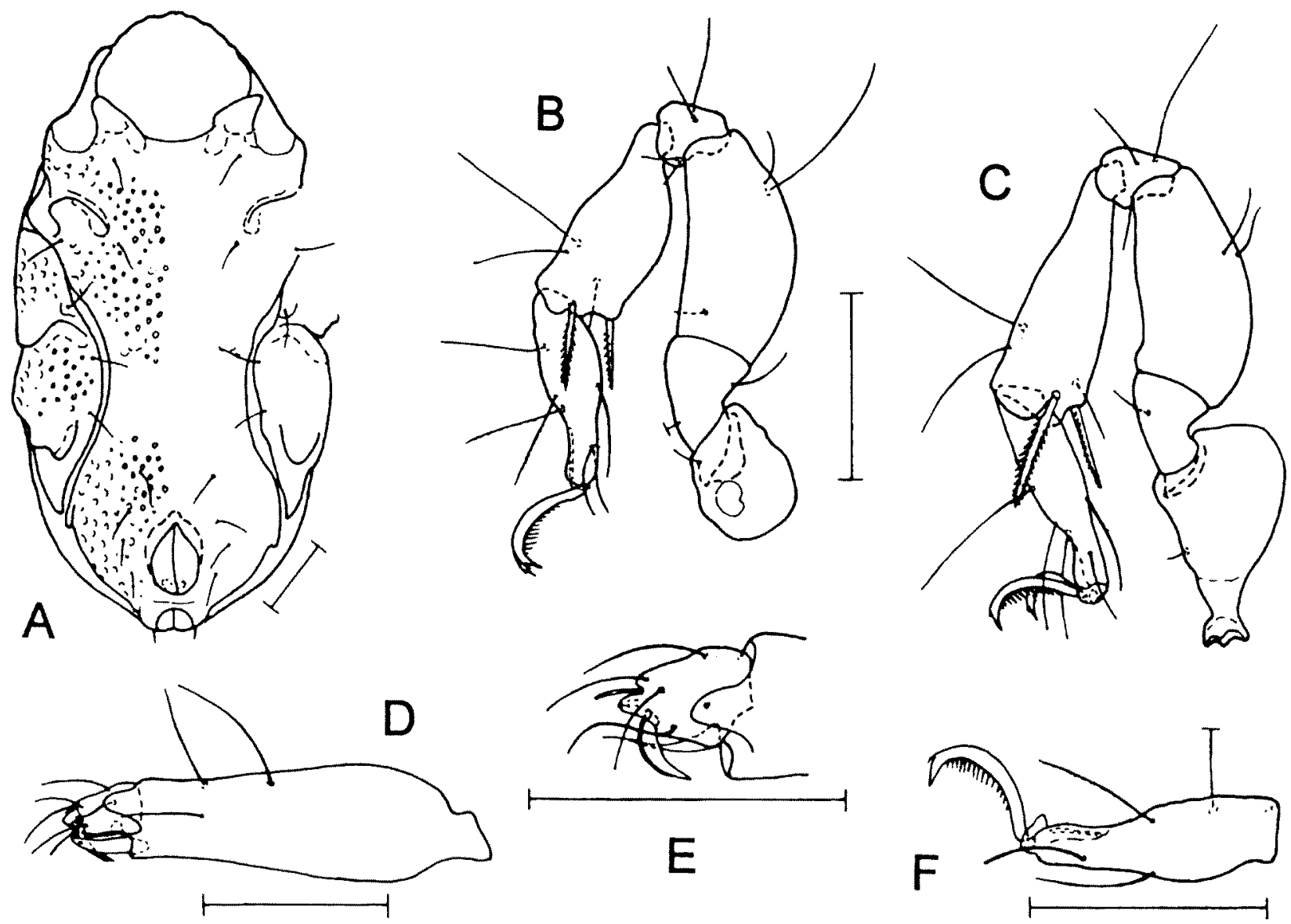

Figure 11 A-F. Simognathus salebrosus sp. nov. A, Idiosoma, ventral, female; B, leg II, medial, female; C, leg IV, medial, female; D, tibia and tarsus I, medial, female; E, posterior part of tibia and tarsus I, medial, female (ventromedial seta and ventral spine of tibia omitted, lateral pas and claw omitted); F, tarsus II, medial, female (lateral pas and claw omitted). Scale $=50 \mu \mathrm{m}$ 
are almost contiguous but not fused. In $S$. abnormalus variants are known with the GA and PE either fused or separated (Otto, 2000a). Simognathus salebrosus and $S$. abnormalus differ in that in the former species the AD is foveate throughout, in $S$. abnormalus the anterolateral portions are nonfoveate.

With the shape of leg I, the tibia being highest in the basal third, then tapering towards the rotated distal portion, and a very short tarsus, this Simognathus resembles Acaromantis species. The three-segmented palps and the presence of paired claws associated with the median claw are characters of the genus Simognathus.

Conspicuous of $S$. salebrosus, and also of $S$. abnormalus, is that epimera I and II form large marginal fossae. The distal part of trochanters I and
II are within these epimeral fossae while the articulation of the trochanters is protected by the epimeral processes.

\section{Distribution}

Indian Ocean, Western Australia, Dampier. From a tidal beach area.

\section{Simognathus tener sp. nov. \\ Figures 12A-J, 13A-D}

\section{Material Examined}

\section{Holotype}

Male, Dampier, $20^{\circ} 39^{\prime} \mathrm{S}, 116^{\circ} 42^{\prime} \mathrm{E}$, Western Australia, Australia; beach in recreation area, coarse
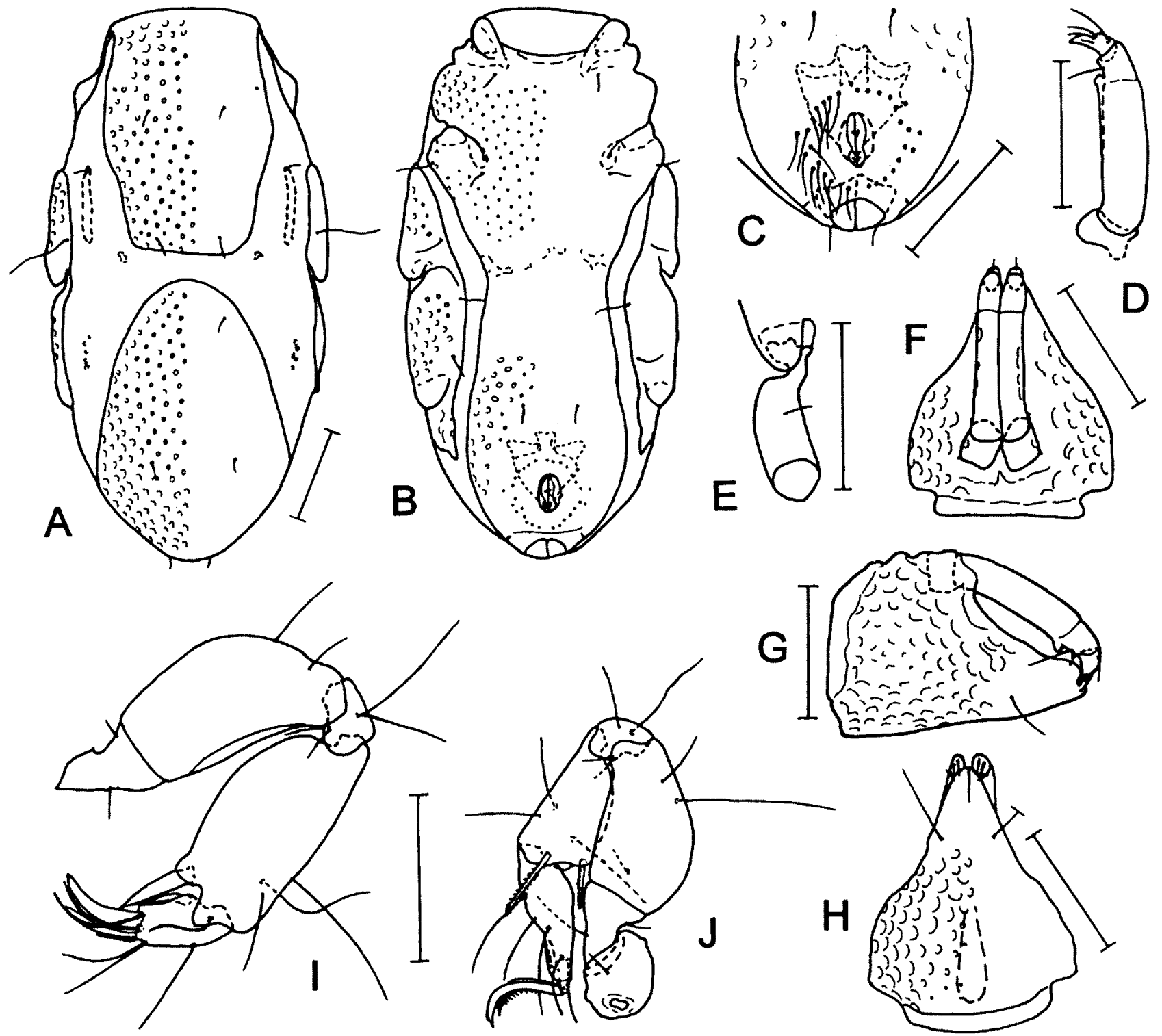

E
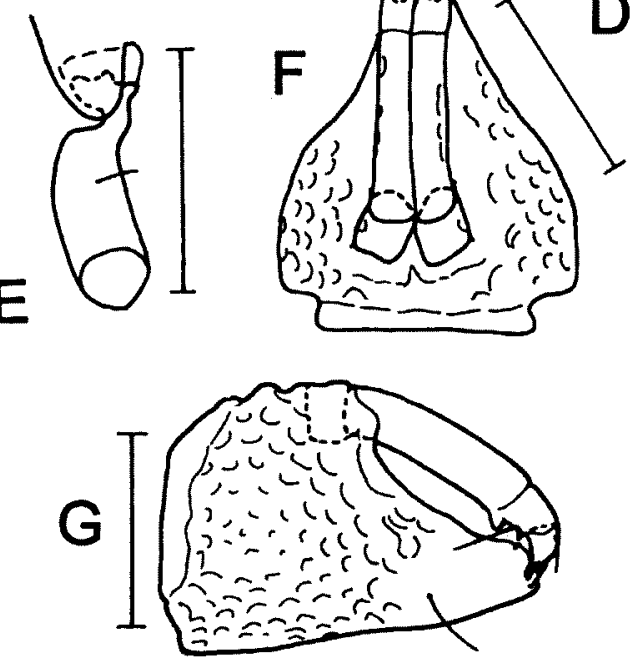

Figure 12 A-J. Simognathus tener sp. nov. A, Idiosoma, dorsal, male; B, idiosoma, ventral, male; C, genital area, male; D, palp, medial, female; E, insertion of trochanter IV, ventral, male; F, gnathosoma, dorsal, male; G, gnathosoma, lateral, female; H, gnathosoma, ventral, male; I, basifemur to tarsus I, medial, male; J, leg II, medial, male. Scale $=50 \mu \mathrm{m}$. 
sand, mid-tide, $0-3 \mathrm{~cm}$ sediment depth, 3 August 2000, coll. I. Bartsch (WAM T52108).

\section{Paratype}

Australia: Western Australia: 1 female, collecting data same as above (WAM T52109).

\section{Etymology}

Specific name derived from tener, Latin, delicate, referring to the delicate ornamentation of the plates.

\section{Diagnosis}

Idiosomal length 290-320 $\mu \mathrm{m}$. Dorsal plates punctate, surface with small, faint foveae. AD shorter than PD. OC elongate, covered by membraneous integument. Anterior margin of PD ovate. AE and GA fused to elongate ventral shield; its surface covered by very delicate foveae. Foveae absent in area representing anterior portion of GA. Gnathosomal base foveate. Dorsum with raised cuticular markings, but without a dorsal lamella extending beyond base of palps. Palps long, more than half of idiosomal length. Second palpal segment elongate, with ventral protuberance, seta and an apical triangular lamella. Length of tibia I twice its height. Ventral spine on tibia I long, evenly tapering. Tarsi II to IV with six setae each, parambulacral setae included (solenidia omitted).

\section{Description}

Male

Idiosoma. Male. Length $290 \mu \mathrm{m}$, width $150 \mu \mathrm{m}$; length:width ratio 1.9 . Dorsal plates evenly punctate, surface with delicate foveae (Figure 12A). Length of $\mathrm{AD} 130 \mu \mathrm{m}$, width $92 \mu \mathrm{m}$; posterior margin truncate. Gland pores tiny, near lateral margin. AD with ds- 1 and ds-3, the latter removed from lateral margin of plate. Pair of ds-2 on $O C$ which is hidden beneath striae of membraneous integument. Length of PD $147 \mu \mathrm{m}$, width $102 \mu \mathrm{m}$; anterior margin ovate. PD with ds-4 and ds-5 (in holotype one of ds-4 lacking). Setae ds-6 in marginal position.

Ventral plates evenly punctate; surface largely covered by small, delicate foveae; these foveae absent in an area representing anterior part of GA and around GO (Figure 12B). AE and GA fused to a ventral shield; its length $263 \mu \mathrm{m}$, width $122 \mu \mathrm{m}$. Epimeral processes I to IV forming large lamellae (Figures 12B and E). PE extending posteriad beyond insertion of leg IV. AE with three pairs of setae; the two posterior ones at almost the same level. GO small, length $20 \mu \mathrm{m}$, width $12 \mu \mathrm{m}$. GA with one pair of outlying setae and 31 slender setae around GO. Spermatopositor extending beyond ring of pgs (Figure 12C).

Gnathosoma. Coarsely foveate (Figures $12 \mathrm{~F}-\mathrm{H}$ ); its length $97 \mu \mathrm{m}$, width $75 \mu \mathrm{m}$. Dorsum of gnathosomal base roughly textured, without lamelliform tectum (Figure 12F); pair of lateral lamella enclosing P-1 (Figure 12G). Palps slender; second palpal segment long, about 0.6 of gnathosomal length; segment with ventromedial lamella and protuberance (Figure 12D), strong ventral seta, and triangular, distolateral lamella. The latter discernible in dorsolateral aspect.
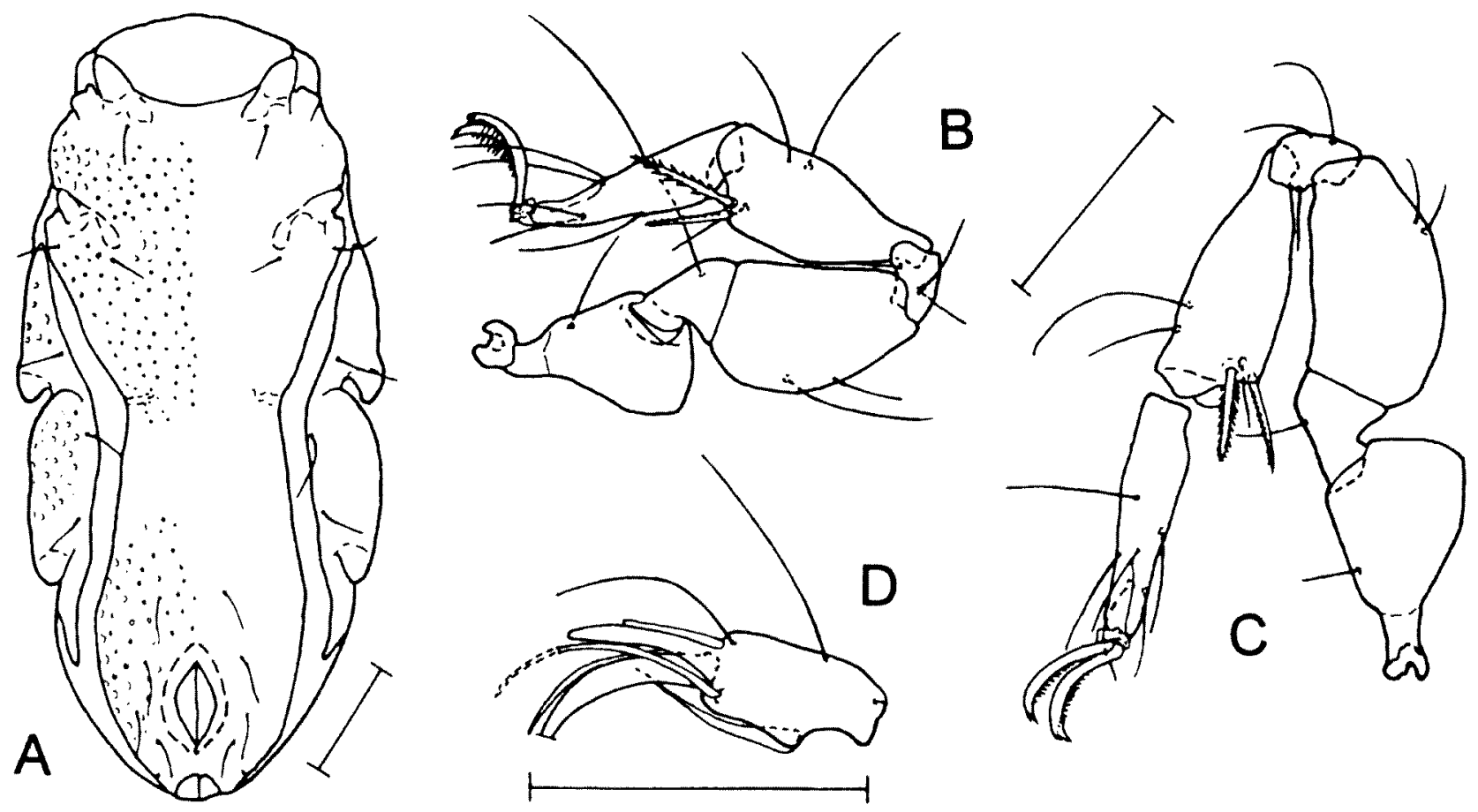

Figure 13 A-D. Simognathus tener sp. nov. A, Idiosoma, ventral, female; B, leg III, medial, female; C, leg IV, medial, female; D, tarsus I, lateral (medial setae and claw omitted, lateral pas in holotype broken), male. Scale $=50 \mu \mathrm{m}$. 
Legs. Telofemur and tibia I almost equal in length. Tibia II shorter than telofemur II. Base of tibia I cylindrical, then abruptly widened and almost equal in height in posterior half of segment (Figure 12I). Tibiae II to IV clavate (Figures 12J, 13B and C). Leg chaetotaxy (pas included, solenidion excluded): leg I, 1, 2, 2, 4, 5, 6; leg II, 1, 2, 3, 4, 5, 6; legs III and IV $1,1,2,3,5,6$. Ventral spine of tibia I without basal apophysis but evenly tapering; medial seta flagellate. Tibiae II to IV each with two coarsely bipectinate setae. Each of tarsi I to IV with three dorsal setae, one ventral seta and a pair of pas. That ventral seta on tarsus I basally stout, then tapering. Solenidion of tarsus I setiform, famulus lamelliform (Figure 13D).

Median claw on tarsus I large, smooth, paired claws similar in length but slender, resembling parambulacral setae. Paired claws of tarsi II to IV with pectines, each with numerous tines.

Female

Length $320 \mu \mathrm{m}$. Dorsal aspect resembling that of male. Ventral plates AE and GA fused (Figure 13A). GA with four pairs of pgs.

\section{Remarks}

Simognathus tener and S. aspidiotus Otto, 2000 share numerous characters, the $\mathrm{AE}$ and GA form a ventral shield; the males have a single pair of outlying setae, the palps are long and slender, the second segment is provided with a protuberance and distal lamella; tarsi II to IV each bear one ventral seta and a pair of pas. Simognathus tener has more slender dorsal plates and more delicate foveae than S. aspidiotus.

Species with a ventral shield are $S$. abnormalus, $S$. aspidiotus Otto, 2000, S. clypeatus Otto, 2000, S. gibberosus Bartsch, 1994, S. salebrosus, S. scutatus Bartsch, 1993, S. tener, S. tropicalis Chatterjee \& de Troch, 2000, and S. uniscutatus Bartsch, 1994 (Bartsch 1993, 1994a; Chatterjee \& de Troch, 2000; Otto, 2000a).

In contrast to the other above species, the $\mathrm{AD}$ of S. gibberosus bears a hyaline lens. S. abnormalus and S. salebrosus have an Acaromantis-like tibia I, elongate and rotated. In S. scutatus all ventral plates are fused, there are no striae of membraneous integument between AE and PE. Tarsi III and IV of S. uniscutatus have a ventral seta and a single pas, the medial but no lateral pas. In contrast, tarsi III and IV of S. aspidiotus, S. clypeatus and S. tener each bear a ventral seta and both a medial and lateral pas; in S. clypeatus one of the pas is doubled. The three species can be separated on the base of the ornamentation of the dorsal and ventral plates; the ventral plates are almost smooth in S. clypeatus, delicately foveate in $S$. tener and coarsely foveate in $S$. aspidiotus. The description of $S$. tropicalis, by Chatterjee \& de Troch (2000), presents no information on the arrangement and number of the pas.

According to Otto (2000a), the male of $S$. gibberosus (housed in the WAM) has the AE and GA separated. A re-examination of that male showed that the $\mathrm{AE}$ and GA are fused to a ventral shield but there is a rupture. Most likely, the slide had been pressed seriously, a pressure and distortion which caused a split in the integument of the mite which was soaked and hardened by the mounting medium (glycerin jelly). The rupture largely follows the borders of the relevant plates. Hence, according to present knowledge, males of $S$. gibberosus have a ventral shield.

\section{Distribution}

Indian Ocean, Western Australia, Dampier. From a tidal beach.

\section{Simognathus uniscutatus Bartsch, 1994 \\ Figure 14A-D}

Simognathus uniscutatus Bartsch, 1994a: 145, figures $45-52$.

\section{Material Examined}

Australia: Western Australia: 1 female, Enderby Island, West of Rocky Head, $20^{\circ} 32.1^{\prime} \mathrm{S}, 116^{\circ} 26.7^{\prime} \mathrm{E}$, sponge garden, 2-13 m, unsorted sandy deposits, 3 August 2000, coll. C. Bryce (WAM T52110).

\section{Diagnosis}

Idiosomal length $390 \mu \mathrm{m}$. Dorsal plates densely punctate and distinctly foveate. AD shorter than $\mathrm{PD}$ (Figure 14A). Anterior margin of PD truncate. OC reduced to oblong sclerite beneath striae of integument. Pair of ds-2 in anterior edge of that platelet. AE and GA fused (Figure 14B). This ventral shield with small foveae except for a smooth median portion representing anterior part of GA. AE with large epimeral processes. Female GA with four pairs of sgs. Gnathosomal base foveate; dorsally with raised cuticular ornamentation but without tectumlike lamella (Figure 14C). Second palpal segment elongate, with ventral protuberance, a seta and a triangular lamella. Leg chaetotaxy (solenidia omitted, pas included): leg I , 1, 2, 2, 4, 5, 6; leg II, 1, 2, 3, 4, 5, 6; legs III and IV , 1, 1, 2, 3, 5, 5. Tibia I short, with cylindrical base, then conspicuously widened (Figure 14D); its ventral spine evenly tapering, without apophysis. Pair of ventral spines on tibiae II to IV distinctly bipectinate. Tarsi I and II each with a wide ventral seta and a pair of eupathid pas; tarsi III and IV with a ventral seta and a single medial pas. On tarsus IV ventral seta and pas situated almost adjacent. Tarsus I with large median and slender paired claws. Paired claws of the following legs with coarsely dentate pectines. Central sclerite with small process. 

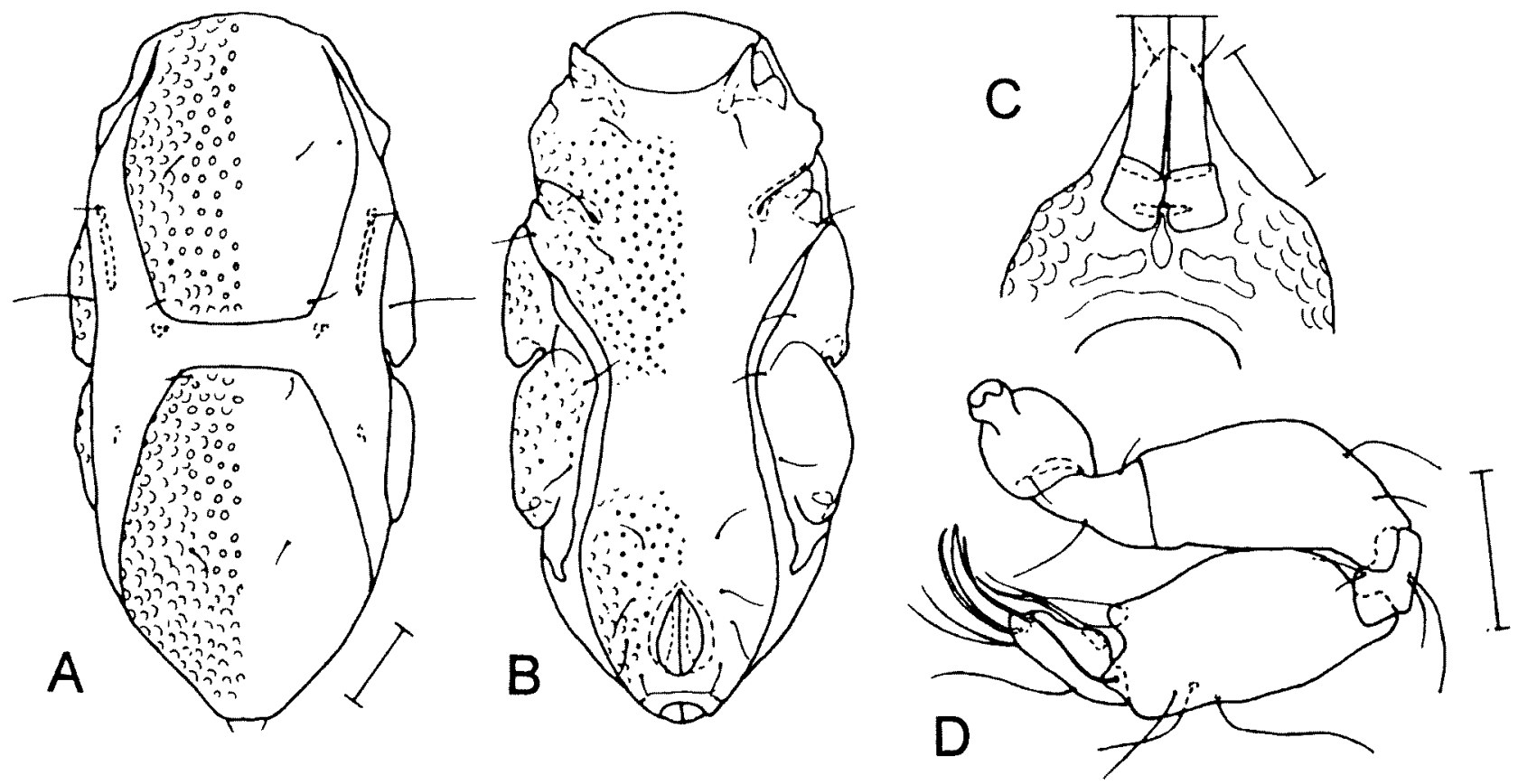

Figure 14 A-F. Simognathus uniscutatus Bartsch, 1994, female. A, Idiosoma, dorsal; B, idiosoma, ventral; C, part of gnathosoma, dorsal; D, leg I, medial. Scale $=50 \mu \mathrm{m}$.

\section{Remarks}

The present female is larger than the holotype female from Rottnest Island, Western Australia (390 $\mu \mathrm{m}$ vs $322 \mu \mathrm{m}$ ) and basifemur I bears two instead of three setae, as present in the holotype of Simognathus uniscutatus. Two setae on basifemur I is the usual number in the majority of Simognathus species and the presence of three setae is expected to be an anomaly and of no taxonomic relevance.

\section{Distribution}

Western Australia, Rottnest Island and Dampier.

\section{FAUNAL COMPARISON}

From Australia, information on psammophilous halacarid species is available from Rottnest Island and Dampier, Western Australia, and the Great Barrier Reef Marine Park and Coral Sea, Queensland. Though the data sets are far from complete, a preliminary comparison of the faunas can be made.

Rottnest Island, at a latitude of about $32^{\circ} \mathrm{S}$, is characterized by numerous sandy beaches separated by limestone platforms. The beaches, with different exposure to waves and currents, demonstrate a variety of grain size composition. Rottnest Island lies in a transition zone between the warm-temperate and tropical zone (Wells and Walker, 1993).

Dampier is in the tropical arid zone, at about $20^{\circ} \mathrm{S}$. The coastline is dominated by muddy and silty flats or mud-covered rocky platforms in the mid-and lower tidal zone, rocks, boulders and mangroves in the higher tidal area. Sandy deposits with coarse and medium-sized grains are rare. The subtidal sediment immediately off Dampier is rich in organic material but around the outer islands of the Dampier Archipelago there are coarse sediments.

The tropical Great Barrier Reef Marine Park and adjacent Coral Sea cover a latitudinal area from about $14^{\circ}$ to $21^{\circ} \mathrm{S}$. There is a variety of different substrata, amongst others areas with fine to coarse sand and coral rubble.

The number and extent of collections performed in the three areas Rottnest Island, Dampier and Great Barrier Reef vary from sampling just once, during a short stay of about two and a half weeks (Rottnest Island, Dampier) to numerous collections taken in a period of about two years (Great Barrier Reef). Additional species (Table 1) are expected to be found in all three areas.

Table 1 Halacarid genera and number of psammophilous species recorded from the Dampier area, Rottnest Island, the Great Barrier Reef and Coral Sea.

\begin{tabular}{lccc}
\hline & Dampier & $\begin{array}{c}\text { Rottnest } \\
\text { Island }\end{array}$ & $\begin{array}{c}\text { Great Barrier Reef, } \\
\text { Coral Sea }\end{array}$ \\
\hline Actacartus & 2 & 2 & 4 \\
Anomalohalacarus & 1 & 1 & 0 \\
Arhodeoporus & 1 & 2 & 7 \\
Copidognathus & 1 & 7 & 14 \\
Scaptognathides & 2 & 1 & 3 \\
Scaptognathus & 1 & 2 & 8 \\
Simognathus & 4 & 7 & 12 \\
\hline
\end{tabular}


Table 2 Psammophilous halacarid species from Dampier area and notes on records from other areas. + , record; - , no record

\begin{tabular}{ll}
\hline Dampier & Other areas \\
\hline Actacarus pacificus & + (Rottnest I., Hokkaido, \\
& Hawaiian Is, Robinson \\
Actacarus festivus & - \\
Anomalohalacarus dampierensis & - \\
Arhodeoporus corallicolus & + (Great Barrier Reef) \\
Copidognathus meridianus & - \\
Scaptognathides hawaiiensis & + (southern China, \\
& Hawaiian Is) \\
Scaptognathides ornatus & + (Hawaiian Is) \\
Scaptognathus exquisitus & + (Great Barrier Reef) \\
Simognathus salebrosus & - \\
Simognathus platyaspis & + (Great Barrier Reef) \\
Simognathus tener & - \\
Simognathus uniscutatus & + (Rottnest I.) \\
\hline
\end{tabular}

In the Dampier area, the collection from sandy deposits and coral fragments contained 12 species, seven of them have been recorded previously from other areas, two species from the Indian and six from the Pacific Ocean and adjacent basins, three from the Great Barrier Reef and three from the Hawaiian Islands (Table 2). The data on the psammobiont halacarid fauna corroborates an assumption of the presence of a rather uniform tropical coastal fauna from North West Cape across the northern Australian coastline to Queensland and also to the Hawaiian Islands. Yet, because of the small size of psammobiont halacarids and hence difficulties in recognizing details, the presence of cryptic species cannot be excluded. Studies on the tidal rhombognathine halacarids from Dampier also demonstrated close similarities with the fauna of the northeastern Australia (Bartsch, 2003a).

\section{ACKNOWLEDGEMENTS}

The samples were taken in July and August 2000 during the Woodside Dampier Marine Biological Workshop which was organized by Dr Fred Wells and Di Jones, Western Australian Museum, and Prof. Diana Walker, The University of Western Australia. Clay Bryce provided me with subtidal sediments from the outer islands. The workshop was sponsored by Woodside Energy Ltd and accomodation was provided by Hamersley Iron Pty. Ltd. My flight to Australia was financed by the German Research Foundation (DFG). Dr H. Dastych arranged loan of specimens housed in the Zoological Institute and Zoological Museum in Hamburg. To all my sincerest thanks.

\section{REFERENCES}

Abé, H. (1996). A new species of the genus
Anomalohalacarus (Acari: Halacaridae) from Japan with notes on taxonomic characters. Journal of the Acarological Society of Japan 5: 7-16.

Abé, H. (1997). Halacarid mites of the genus Actacarus (Acari: Halacaridae) from Hokkaido, Northern Japan. Species Diversity 2: 31-42.

Bartsch, I. (1976a). Beitrag zur Halacariden-Fauna (Halacaridae, Acari) der Bretagneküste. Beschreibung von fünf Arten aus dem Sandlückensystem. Acarologia 17: $652-667$.

Bartsch, I. (1976b). Ergänzungen zur Halacariden-Fauna (Halacaridae, Acari) im Becken von Arcachon. Vie et Milieu, série A 26: 31-46.

Bartsch, I. (1979). Halacaridae (Acari) from Oahu Island (Hawaiian Archipelago). Entomologische Mitteilungen aus dem Zoologischen Museum Hamburg 6: 231-241.

Bartsch, I. (1981a). Halacaridae (Acari) aus dem Kanal von Moçambique. Cahiers de Biologie marine 22: 35-63.

Bartsch, I. (1981b). Die Gattungen Anomalohalacarus und Halacaroides (Halacaridae, Acari), geographische Verbreitung, Bestimmnungstabelle und Beschreibung dreier neuer Arten. Zoologische Beiträge, Neue Folge 27: 67-84.

Bartsch, I. (1982). Weitere Halacaridae (Acari) aus dem Kanal von Moçambique. Cahiers de Biologie marine 23: 435-457.

Bartsch, I. (1985a). Notes on the Halacaridae (Acari) of Yorkshire. Naturalist 110: 41-48.

Bartsch, I. (1985b). New species of Halacaridae (Acari) from New Zealand. New Zealand Journal of Zoology 12: 175-185.

Bartsch, I. (1988). Arenicolous Halacaridae (Acari) in Hawaiian waters. Proceedings, Hawaiian Entomological Society 28: 213-228.

Bartsch, I. (1991a). Taxonomic notes on halacarids (Acari) from the Skagerrak area. Helgoländer Meeresuntersuchungen 54: 97-106.

Bartsch, I. (1991b). Arhodeoporus mactanus n. sp., a new species of marine mite (Acari, Halacaridae), from the Philippines. The Philippine Journal of Science 120: 2125.

Bartsch, I. (1991c). Arenicolous Halacaridae (Acari) from Hong Kong. Asian Marine Biology 8: 57-75.

Bartsch, I. (1993). Arenicolous Halacaridae (Acari) from Rottnest Island, Western Australia, In F.E. Wells, D.I. Walker, H. Kirkman and R. Lethbridge (eds), The Marine Flora and Fauna of Rottnest Island, Western Australia: 73-103.

Bartsch, I. (1994a). The genus Simognathus (Acari, Halacaridae), description of six new species from southern Australia and a tabular key to all species. Acarologia 35: 135-152.

Bartsch, I. (1994b). Copidognathus (Halacaridae: Acari) from Western Australia. Description of twelve species of the gibbus group. Records of the Western Australian Museum 16: 535-566.

Bartsch, I. (2000). Rhombognathinae (Acari: Halacaridae) from the Great Barrier Reef, Australia. Memoirs of the Queensland Museum 45: 165-203.

Bartsch, I. (2003a). Rhombognathine mites (Halacaridae: Acari) from Dampier, Western Australia: taxonomy and biogeography. In F. E. Wells, D. I. Walker and D. 
Jones (eds), Proceedings of the Eleventh International Marine Biological Workshop: The Marine Flora and Fauna of Dampier; Western Australia (in press)

Bartsch, I. (2003b). A new arenicolous Copidognathus (Halacaridae: Acari) from Dampier, Western Australia, In F. E. Wells, D. I.Walker and D. Jones (eds), Proceedings of the Eleventh International Marme Biological Workshop: The Marine Flora and Fauna of Dampier; Western Australia (in press)

Chatterjee, T. and de Troch, M. (2000). Halacaridae (Acari) from Gazi Bay (Kenya): description and biogeography of three new and two known species. Hydrobiologia 427: 177-194.

Krantz, G.W. (1971). The mites of Quintana Roo. II. Actacarus giganteus, a new species of arenicolous mite (Prostigmata: Halacaridae) from the Caribbean coast. Annals of Entomological Society of America 64: 594-598.

Monniot, F. (1967). Deux halacariens endopsammiques: Halacarus anomalus Trouessart 1894 et Halacarus marcandrei n. sp. Cahiers de Biologie Marine 8: 89-98.

Morselli, I. \& Mari, M. (1981). Anomalohalacarus affinis n. sp., un alacaride (Halacaridae: Acari) delle coste Toscane. Atti della Societa Toscana di Scienze Naturali, Memorie, Serie B 87: 275-283.

Morselli, I. \& Mari, M. (1982). Alacaride (Acari, Prostigmata) di fondi sabbiosi della costa Ionica del Salento. Atti della Societa Toscana di Scienze Naturali, Memorie, Serie B 88: 229-247.

Morselli, I. and Mari, M. (1989). Halacarids (Halacaridae: Acari) of the Leghorn coast. V. Anomalohalacarus affinis, a new interstitial infralittoral species. Bolletino di Zoologia 56: 105-108.

Newell, I.M. (1971). Halacaridae (Acari) collected during cruise 17 of the R/V Anton Bruun, in the southeastern Pacific Ocean. Anton Bruun Report 8: 3-58.

Newell, I.M. (1984). Antarctic Halacaroidea. Antarctic Research Series 40: 1-284.

Nicholls, A.G. (1935). Copepods from the interstitial fauna of a sandy beach. Journal of the Marine Biological Association of the United Kingdom 20: 379-405.

Otto, J.C. (1999a). Halacarid fauna of the Great Barrier Reef and Coral Sea: the genera Agallopsis and Halacaropsis (Acarina: Halacaridae). Memoirs of the Queensland Museum 43: 797-817

Otto, J.C. (1999b). Corallihalacarus chilcottensis, a new genus and species of marine mite from the Coral Sea (Acarina: Halacaridae). Zoological Science 16: 839-843.

Otto, J.C. (2000a). Simognathinae (Acarina: Halacaridae) from the Great Barrier Reef and Coral Sea, description of thirteen new species. Memoirs of the Queensland Museum 45: 505-534.

Otto, J.C. (2000b). Halacaridae from the Great Barrier Reef and Coral Sea: The genera Lohmannella, Scaptognathides and Scaptognathus (Acarina: Halacaridae: Lohmannellinae). Memoirs of the Queensland Museum 45: 535-555
Otto, J.C. (2000c). Acarochelopodia and Actacarus species (Acari: Halacaridae) from Australia, with remarks on A. pacificus and A. orthotectus. Species Diversity 5: 111127

Otto, J.C. (2000d). Australacarus (Acari: Halacaridae) from northern Australia, with description of three new species. Records of the Western Australian Museum 20: 103-114

Otto, J.C. (2000e). Xenohalacarus longirostris n.gen., n.sp., a marine mite (Acari: Halacaridae: Lohmannellinae) from Chilcott Islet. Australia. International lournal of Acarology 26: 285-291.

Otto, J.C. (2000f). Six closely related species of the Copidognathus gibbus group (Acarina: Halacaridae) from north-eastern Australia. Cahiers de Biologie marine 41: 223-232.

Otto, J.C. $(2000 \mathrm{~g})$. Seven new species of Arhodeoportis (Acarina: Halacaridae) from the Great Barrier Reef and Coral Sea. Hydrobiologia 436: 1-16.

Otto, J. (2001a). A new species of Mictognathus (Acari: Halacaridae) from the Great Barrier Reef. Pacific Science 55: 43-46.

Otto, J. (2001b). Halacaridae of the Great Barrier Reef Lagoon and Coral Sea: Halacarellus and Halacarus. (Acarina: Halacaroidea). Memoirs of the Queensland Museum 46: 691-716.

Otto, J. (2001c). Halacaridae of the Great Barrier Reef Lagoon and Coral Sea: The Copidognathus ornatus group (Acarina: Prostigmata: Halacaridae). Memoirs of the Queensland Museum 46: 717-731

Otto, J.C. \& Bartsch, I. (1999). Tropihalacarus spio, a new genus and species of Halacaridae (Acarina: Prostigmata) from the Great Barrier Reef. Acarologia 40: $171-178$.

Proches, S. (2002). The first records of the genus Simognathus (Acari:Halacaridae) from southern Africa, with a species description. African Entomology 10: $354-356$

Rao, C.G. (1970). On some interstitial fauna in the marine sands on Indian coast. Current Science 39: 504-507.

Remane, A. (1940). Einführung in die zoologische Ökologie der Nord- und Ostsee, In G. Grimpe and E. Wagler (eds), Die Tierwelt der Nord- und Ostsee. 1a: 1238 ,

Viets, K. (1936). Zoologische Ergebnisse einer Reise nach Bonaire, Curaçao und Aruba im Jahre 1930. No. 18 Halacariden aus Westindien. Zoologische Jahrbiicher fiir Systematik, Ökologie und Tiergeographie 67: 389-424.

Wells, F.E. and Walker, D.I. (1993). Introduction. In F.E. Wells, D.I. Walker, H. Kirkman and R. Lethbridge (eds), The Marine Flora and Fauna of Rottnest Island Western Australia:1-10. Western Australian Museum, Perth

Manuscript received 10 January 2003; accepted 4 April 2003 